\title{
Evaluation of nitrogen removal processes and microbial communities in eight full-scale municipal wastewater treatment plants
}

\author{
Jia Yan ${ }^{1,2,4}$, Jie-Hui Xie ${ }^{1}$, Si-Ji Wang ${ }^{1}$, Hong-Guo Zhang ${ }^{1,2,3,4}$, Jia-Peng Wu ${ }^{3}$, Yi-Guo Hong ${ }^{1,2,3,{ }^{*}}$ \\ ${ }^{1}$ School of Environmental Science and Engineering, Guangzhou University, Guangzhou 510006, P.R. China \\ ${ }^{2}$ Key Laboratory for Water Quality Security and Protection in Pearl River Delta, Ministry of Education, Guangzhou 510006, P.R. China \\ ${ }^{3}$ State Key Laboratory of Tropical Oceanography (LTO), South China Sea Institute of Oceanology, Chinese Academy of Sciences, \\ Guangzhou 510301, P.R. China \\ ${ }^{4}$ Guangzhou University-Linköping University Research Center on Urban Sustainable Development, Guangzhou University, Guangzhou \\ 510006, P.R. China
}

\begin{abstract}
Wastewater treatment plants (WWTPs) face great challenges in developing countries, such as China, due to increasingly strict integrated wastewater discharge standard, especially for ammonium. Thus, it is very important to understand the limiting factor for ammonium removal in WWTPs. In this study, samples from 8 full-scale municipal WWTPs with different treatment processes in Pearl River Delta (PRD) area were evaluated. Bacterial and archaeal communities were investigated by high-throughput sequencing, activity of aerobic ammonium and nitrite oxidation, denitrification and anammox processes were evaluated. Nitrite, nitrate and TP concentration were strongly correlated with bacterial and archaeal composition in WWTPs based on canonical correspondence analysis (CCA). Aerobic ammonium oxidation activities were over 10 times lower than aerobic nitrite oxidation, denitrification and anammox activities in WWTPs samples, which indicated nitrogen removal activities in WWTPs were limited by aerobic ammonium oxidation, because of lack of nitrite/nitrate for denitrification and anammox. Moreover, a technology-dependent shaping of microbial diversity and nitrogen removal activity was observed. The highest bacterial diversity and nitrogen removal activities were achieved in sequencing batch reactor (SBR) and Modified Anaerobic-Anoxic-Oxic (MAAO) processes, which implied the advantage of these two treatment technologies in nitrogen removal. Therefore, this study suggested enhancing activity of aerobic ammonium oxidation might be a potential solution, for promoting ammonium removal and benefiting sustainable management of WWTPs in future.
\end{abstract}

Keywords: Microbial community, WWTPs, nitrogen removal, activated sludge, Pearl River Delta

* Correspondence to: Yi-Guo Hong, School of Environmental Science and Engineering, Guangzhou University, Guangzhou 510006, P.R. China; Key Laboratory for Water Quality Security and Protection in Pearl River Delta, Ministry of Education, Guangzhou 510006, P.R. China; State Key Laboratory of Tropical Oceanography (LTO), South China Sea Institute of Oceanology, Chinese Academy of Sciences, Guangzhou 510301, P.R. China; E-mail: yiguohong@gzhu.edu.cn

Received: February 2, 2019; Accepted: March 19, 2019; Published Online: April 15, 2019

Citation: Jia Yan, Jie-Hui Xie, Si-Ji Wang, Hong-Guo Zhang, Jia-Peng Wu, Yi-Guo Hong, 2019. Evaluation of nitrogen removal processes and microbial communities in eight full-scale municipal wastewater treatment plants. Applied Environmental Biotechnology, 4(2): 24-38. http://doi.org/10.26789/AEB.2019.01.007

Copyright: Evaluation of nitrogen removal processes and microbial communities in eight full-scale municipal wastewater treatment plants.@ 2019 Jia Yan et al.. This is an Open Access article distributed under the terms of the Creative Commons Attribution-Noncommercial 4.0 International License, permitting all non-commercial use, distribution, and reproduction in any medium, provided the original work is properly cited and acknowledged.

\section{Introduction}

Nitrogen, which mainly present as ammonium in wastewater, is an important nutrient element for living organisms. Human activities accelerate the fluxes of nitrogen to coastal waters and lakes (Cloern, 2001), which leads to significant eutrophication. Eutrophication becomes a serious environmental problem in developing countries, such as China, with development of economics during last a few decades (Huang et al., 2003; Le et al., 2010).

Municipal wastewater treatment plants (WWTPs) are able to remarkably reduce carbon, nitrogen and phosphorus concentration in wastewater, through biological treatment processes. Because of the water shortage crisis and pollution in China, national discharging standard for municipal WWTPs has been upgraded a few times during past years, which currently requires ammonium concentration in effluent of all municipal WWTPs to be lower than $5 \mathrm{mg} \mathrm{L}^{-1}$. This requirement brings a great challenge to design and operation of WWTPs (Qiu et al., 2010), to meet this requirement, it is important to better understanding nitrogen removal pathway in WWTPs with different treatment processes.

Nitrification and denitrification is the most widely used nitrogen removal processes in WWTPs. Nitrification is a two-step process, ammonium is firstly oxidized to nitrite by aerobic ammonia-oxidizing bacteria (AOB), and nitrite 
can be further converted to nitrate through aerobic nitrite oxidation, which is performed by aerobic nitrite oxidizing bacteria (NOB), the produced nitrite and nitrate can be reduced to di-nitrogen gas via denitrification (Fisher, 1985; Zhang et al., 2011; Wang et al., 2014). Recently, since the discovery of archaeal ammonia-oxidation (Könneke et al., 2005; Tourna et al., 2011), anaerobic ammonium oxidation (anammox) (Jetten et al., 2001) and complete ammonium oxidation (comammox) (Van et al., 2015), which provide different biochemical pathways in nitrogen removal. Nitrogen removal is no longer strict to traditional nitrification and denitrification processes, but becomes a very complicated network. Aerobic ammonia-oxidizing archaea (AOA) and anammox bacteria have been proved to play important roles in nitrification and nitrogen loss in marine oxygen minimum zones (Thamdrup and Dalsgaard, 2002; Arrigo, 2005) and land-freshwater interface (Zhu et al., 2013). AOA and anammox bacteria are widespread in WWTPs (Park et al., 2006; Bai et al., 2012; Wang et al., 2015), but the presence of comammox bacteria is nonubiquity, which may be outcompeted by non-comammox Nitrospira (Gonzalez-Martinez et al., 2016). Nevertheless, the contribution of archaeal ammonia-oxidation, anammox and comammox processes to nitrogen removal are different over studies (Park et al., 2006; Bai et al., 2012; Wang et al., 2015; Gonzalez-Martinez et al., 2016; Fan et al., 2017; Pan et al., 2018), which might be related to different operational parameters and treatment biotechnologies over sampling WWTPs.

Biological activity in municipal WWTPs is strongly related to the treatment biotechnologies (Brenner, 2010; $\mathrm{Hu}, 2012$ ), by affecting the composition and of microbial communities and activities of microbes ( $\mathrm{Hu}, 2012)$. Many molecular methods have been used to understand microbial community structures in WWTPs, including fluorescence in situ hybridization (FISH) (Wang et al., 2014), construction of clone library (Wang et al., 2015; Figuerola and Erijman, 2010), real-time quantitative PCR analysis (Bai et al., 2012; Wang et al., 2015; Hai et al., 2014; Meng et al., 2017) and high-throughput sequencing (Fan et al., 2017, Cortés-Lorenzo et al., 2014; Ma et al., 2015; Harter et al., 2016; Sun et al., 2018). Anaerobic-anoxic-oxic (AAO), oxidation ditch (OD) and sequencing batch reactor (SBR) processes were most widely used treatment biotechnologies for municipal wastewater (Qiu et al., 2010). Therefore, to enhance nitrogen removal and meet requirement of national discharging standard for municipal WWTPs, it is worthwhile to access better understanding of microbial communities and nitrogen removal activity, in WWTPs with AAO, OD and SBR processes.

In this study, 45 samples were collected from eight WWTPs, with AAO, modified AAO, OD (OD and AAOD) and SBR processes. Bacterial and archaeal communities were analyzed by Illumina high-throughput sequencing. Statistical analyses were performed on bacterial and archaeal
16S rRNA genes, to compare correlations of bacteria and archaea with chemical factors in wastewater. Moreover, the potential activity of aerobic ammonium oxidation, aerobic nitrite oxidation, denitrification and anammox of all WWTP samples were detected and compared among all WWTP samples. The aim of this study was to understand the potential linking of microbial community, nitrogen removal activity and treatment biotechnology in WWTPs. Then, potential solution for promoting ammonium removal in WWTP was discussed.

\section{Materials and Methods}

\subsection{WWTPs for Sampling}

Activated sludge samples were collected from eight full-scale WWTPs in PRD China, details for location and treatment biotechnology were shown in Table 1, Fig. 1 and Fig. S1. To minimum the effect of living culture, temperature and sampling time, all samples were collected in a week, and all sampling WWTPs were located within one province. Aerobic and anoxic sludge samples were taken from oxic/aerobic and anoxic tank/area of biological treatment system, respectively. There was only one sample be taken from SBR process, since both aerobic and anoxic treatment were taken place in a single tank. All sampling WWTPs were located in main cities in Guangdong province of China, where population densities were relatively higher. Three samples were taken within the same week (in July 2017) as parallel samples for each WWTPs. All 45 samples were used for chemical factors and activity assays, but only a mixed sample of three parallel samples from each WWTP was used for investigation of microbial composition (15 samples). Dissolve oxygen concentration was automatically controlled at $1.5-2.0 \mathrm{mg} \mathrm{L}^{-1}$ in aerobic tank/area or period in all sampling WWTPs. Since all samples were taken within a narrow area, the temperature in all sampling tanks were about $25.5 \pm 1.5^{\circ} \mathrm{C}$. All samples collected from WWTPs were carefully transported to the laboratory as soon as possible after sampling. Activated sludge samples were used for activity assays, quantification of protein concentration and DNA extraction after gravity settling, the resulted supernatants were stored at $-20^{\circ} \mathrm{C}$ until chemical analyses after centrifuge.

\subsection{DNA Extraction, PCR Amplification and Raw Data Analysis for High-throughput Sequencing}

Sludge sample $(2 \mathrm{~mL})$ was centrifuged at $10000 \mathrm{rpm}$ for 3 min, the resulted pellet was used for DNA extraction. The primer set of $341 \mathrm{~F} / 805 \mathrm{R}$ was used to amplify bacterial $16 \mathrm{~S}$ rRNA gene (Herlemann et al., 2011). A nested PCR was performed for amplification of the archaeal 16S rRNA gene, primer sets of $340 \mathrm{~F}$ and 1000R for primary PCR (Gantner et al., 2011), and primers of 349F/806R for secondary PCR (Takai and Horikoshi, 2000). Paired-end sequencing on Illumina Miseq platform was performed by Sangon 
Biotech (Shanghai, China). Details for PCR amplification, high-throughput sequencing and raw data analysis were described in the supplementary information.(See Supplement Materials for details.

\subsection{Statistical Analysis and Data Deposition}

The qualified sequences were assigned to different operational taxonomic units (OTUs) with $3 \%$ distance cutoff. Archaeal and bacterial communities were analyzed by RDP classifier (version 2.12) (Wang et al., 2007). Rarefaction curve and alpha diversity (ACE, Chaol and Shannon index, Simpsons and Coverage) were calculated by Mothur (version 1.30.1) (Schloss et al., 2009). Canonical correlation analysis (CCA) was conducted by R software (version 3.2) with vegan package (2.0-10) (Cheema et al., 2015). Sequence data were deposited to NCBI with the accession number of SRP153343 and SRP153377.

\subsection{Activity Assays}

Sludge sample after gravity settling was washed 5 times $\mathrm{w}$ phosphate buffer saline (PBS, $300 \mathrm{mM}, \mathrm{pH}$ 7.3). Wast sludge samples $(50 \mathrm{~mL})$ were used for activity assays $\mathrm{w}$ previously reported methods (Yan et al., 2010; Langone al., 2014), in $100 \mathrm{~mL}$ glass flasks (aerobic ammonium oxi tion and nitrite oxidation) and serum bottles (denitrificati and anammox). In short, ammonium concentration of 1 $\mathrm{mM}$ was used in activity assays of aerobic and anaerol ammonium oxidation, nitrite concentration of $0.5 \mathrm{mM} \mathrm{v}$ supplemented in nitrite oxidation, denitrification and anaıımox activity assays. Glucose $\left(1000 \mathrm{mg} \mathrm{L}^{-1}\right)$ was used as carbon source for denitrification. For activity assay of denitrification and anammox processes, gas exchange with nitrogen gas $(99.99 \%)$ for 20 min was performed to removal oxygen. Liquid sample was taken every $30 \mathrm{~min}$ for $3 \mathrm{~h}$, to monitoring substrate consumption. Activities of aerobic and anaerobic ammonium oxidation were calculated by the consumption rate of ammonium, while the activities of aerobic nitrite oxidation and denitrification were evaluated by the consumption of nitrite.

\subsection{Analytical Methods}

Sludge sample $(1 \mathrm{~mL})$ was centrifuged at $13000 \mathrm{rpm}$ for $3 \mathrm{~min}$, the resulted pellet was used for quantification of protein concentration with previously reported method (Yan et al., 2018). Concentration of ammonium was detected by OPA colorimetric method (Yan et al., 2012). Nitrite, nitrate and sulfate in liquid samples were analyzed by ion chromatography (DIONEX ICS-1100, Thermo Fisher, USA). COD and TP concentration were measured by standard methods (APHA et al., 2005).(See Supplement Materials for details.

\section{Results and Discussion}

\subsection{Chemical Properties in Wastewater}

Chemical properties in wastewater of each sampling anoxic and aerobic tank/area municipal WWTPs were evaluated, including $\mathrm{pH}$ value, ammonium, nitrite, nitrate, sulfate, TP and COD concentration, as shown in Table 1. A tiny amount of agricultural and industrial waste water $(<0.01 \%$ flow $)$ were injected into municipal wastewater flow during operation, in DTS, HM and DW WWTPs. Nitrite concentration was lower than the detection limit for most of the samples. With exception of DW and ZSH WWTPs, ammonium concentration was higher than $5 \mathrm{mg} \mathrm{L}^{-1}$, which could not meet the requirement from national discharging standard. TP concentration in HM WWTP was unmorally higher than the other samples, which might indicate high concentration of TP in the injected industrial wastewater.

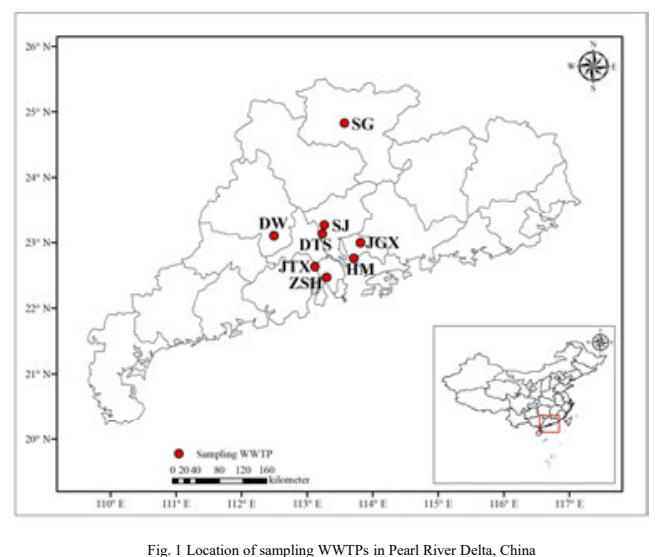

Figure 1. Location of samoling WWTPs in Pearl River Delta, China

\subsection{Microbial Communities in WWTPs}

There were a total of 902,672 qualified bacterial 16S rRNA gene sequences, and 988,524 qualified archaeal 16S rRNA gene sequences be obtained, from all WWTPs samples (see Table 2). Rarefaction curve and Shannon diversity curve of all WWTP samples were shown in Fig. S2, which indicated sufficient sequences have been obtained to investigate microbial diversities of all sludge samples. Richness and diversity indices of bacterial and archaeal communities of all samples indicated a large bacterial and archaeal community in WWTPs. Richness and diversity of bacteria were remarkably higher than archaea. Besides, Shannon index demonstrated the follow technology-dependent trend in bacterial community diversity: $\mathrm{SBR}>\mathrm{OD}>\mathrm{MAAO}>$ $\mathrm{AAOD}>\mathrm{AAO}$.

The number of 114 common bacterial OTUs was observed among all WWTP samples, accounting for about 3.3 - $4.6 \%$ abundance of total OTUs in each sample, see Fig. S3, which was dominated by Alphaproteobacteria, Betaproteobacteria, Gammaproteobacteria, Actionobacteria, Gemmatimonadetes, Planctomycetia and Nitrospira, see Fig. S4. Both carbon 
Table 1. Location, wastewater treatment process and physiochemical analysis of wastewater in sampling WWTPs.

\begin{tabular}{|c|c|c|c|c|c|c|c|c|c|c|c|c|c|c|c|c|c|}
\hline \multirow{2}{*}{$\begin{array}{c}\text { Name } \\
\text { of } \\
\text { WWT }\end{array}$} & \multirow{2}{*}{ Location } & \multirow{2}{*}{$\begin{array}{c}\text { Technology } \\
*\end{array}$} & \multirow[b]{2}{*}{$\mathrm{pH}$} & \multirow[b]{2}{*}{$\mathrm{NO}_{2}^{-}$} & \multicolumn{3}{|c|}{ Anoxic system $(\mathrm{mg} / \mathrm{L})$} & \multirow[b]{2}{*}{$\mathrm{SO}_{4}{ }^{2-}$} & \multirow[b]{2}{*}{$\mathrm{TP}$} & \multirow[b]{2}{*}{$\mathrm{pH}$} & \multirow[b]{2}{*}{$\mathrm{NO}_{2}^{-}$} & \multicolumn{3}{|c|}{ Aerobic system $(\mathrm{mg} / \mathrm{L})$} & \multirow[b]{2}{*}{$\mathrm{SO}_{4}{ }^{2-}$} & \multirow[b]{2}{*}{$\mathrm{TP}$} & \multirow{2}{*}{ Note } \\
\hline & & & & & $\mathrm{NO}_{3}^{-}$ & COD & $\mathrm{NH}_{4}^{+}$ & & & & & $\mathrm{NO}_{3}^{-}$ & COD & $\mathrm{NH}_{4}^{+}$ & & & \\
\hline $\mathrm{ZSH}$ & $\mathrm{N} 22^{\circ} 28^{\prime} 05^{\prime \prime}, \mathrm{E} 113^{\circ} 17^{\prime} 43^{\prime \prime}$ & SBR & 6.8 & 0 & 89.9 & 34.0 & 0 & 938.9 & 2.9 & & & & & & & & \\
\hline SG & $\mathrm{N} 22^{\circ} 49^{\prime} 48^{\prime \prime}, \mathrm{E} 113^{\circ} 34^{\prime} 12^{\prime \prime}$ & OD & 7.3 & 0 & 1.2 & 101.7 & 14.9 & 12.5 & 2.9 & 7.0 & 0 & 3.7 & 172.5 & 16.4 & 682.6 & 1.9 & $\&$ \\
\hline JTX & $\mathrm{N} 22^{\circ} 37^{\prime} 56^{\prime \prime}, \mathrm{E} 113^{\circ} 07^{\prime} 14^{\prime \prime}$ & OD & 6.9 & 0 & 13.0 & 88.4 & 4.9 & 21.1 & 0 & 6.6 & 0 & 38.4 & 103.5 & 11.7 & 1279.7 & 0 & $\&$ \\
\hline JGX & $\mathrm{N} 22^{\circ} 59^{\prime} 44^{\prime \prime}, \mathrm{E} 113^{\circ} 48^{\prime} 39^{\prime \prime}$ & AAOD & 6.8 & 0 & 0 & 108.8 & 25.7 & 22.1 & 19.9 & 7.0 & 0 & 1.9 & 95.8 & 11 & 768.0 & 1.9 & \\
\hline DW & $\mathrm{N} 23^{\circ} 06^{\prime} 16^{\prime \prime}, \mathrm{E} 112^{\circ} 29^{\prime} 24^{\prime \prime}$ & MAAO & 7.0 & 0 & 8.7 & 163.2 & 17.3 & 42.2 & 0.9 & 6.8 & 0.01 & 0 & 27.2 & 3.8 & 1411.2 & 2.9 & $\#$ \\
\hline $\mathrm{HM}$ & $\mathrm{N} 22^{\circ} 45^{\prime} 26^{\prime \prime}, \mathrm{E} 113^{\circ} 42^{\prime} 36^{\prime \prime}$ & MAAO & 7.8 & 0 & 9.3 & 115.6 & 14.9 & 37.4 & 115.9 & 6.5 & 0.11 & 26.7 & 91.5 & 17.3 & 1459.6 & 91.2 & \# \\
\hline SJ & $\mathrm{N} 23^{\circ} 15^{\prime} 10^{\prime \prime}, \mathrm{E} 113^{\circ} 14^{\prime} 46^{\prime \prime}$ & MAAO & 7.4 & 0 & 5.6 & 165.5 & 36.9 & 12.5 & 5.7 & 7.1 & 0 & 34.7 & 95.2 & 9.4 & 597.1 & 2.9 & \\
\hline DTS & $\mathrm{N} 23^{\circ} 07^{\prime} 34^{\prime \prime}, \mathrm{E} 113^{\circ} 12^{\prime} 52^{\prime \prime}$ & AAO & 6.9 & 0 & 8.7 & 170.0 & 9.4 & 13.4 & 11.4 & 6.6 & 0 & 19.2 & 102 & 7.9 & 554.9 & 9.5 & \# \\
\hline
\end{tabular}

*AAO represented Anaerobic-Anoxic-Oxic process; MAAO represented Modified Anaerobic-Anoxic-Oxic process, which introduced a pre-anoxic digestion tank for recycling flow before anaerobic tank; AAOD represented Anaerobic-Anoxic- Oxidation Ditch process; OD represented Oxidation Ditch process, there were both anoxic and aerobic area in this oxidation ditch; SBR represented Sequencing Batch Reactor process; \# injection of industrial or agricultural wastewater during operation to enhance microbial activity; \& Samples were taken in anoxic and aerobic area in oxidation ditch.

and nitrogen conversion bacteria were included in these common OTUs, indicating the presence of shared/core OTUs for biological treatment processes in municipal wastewater treatment. However, there was no shared archaeal OTUs could be achieved among all WWTP samples. Moreover, the unique OTUs in ZSH and DTS _ A were extremely higher (over 600 OTUs) than other samples (90 - 250 OTUs).

Proteobacteria were the most predominant phylum in all WWTP samples, attributed to $39-75 \%$ of total bacteria, followed by three phyla of Bacteroidetes, Planctomycetes and Acideobacteria. Distribution of bacteria and archaea at family level were presented in Fig. S5 and Fig. S6. The family of Rhodocyclaceae, Planctomycetaceae, Comamonadaceae and Chitinophagaceae were relatively abundant in WWTPs. With exception of ZSH WWTP, archaea community was dominated by Methanogenesis in both anoxic and aerobic sludge, which was able to produce methane, including family of Methanoregulaceae, Methanotrichaceae, Methanospirillaceae and Methanobacteriaceae. This phenomenon might relate to sludge recycling in AAO, MAAO and OD processes, which led to mixed anoxic and aerobic sludge. Aerobic ammonia-oxidizing archaea was dominated archaea in sample from ZSH WWTP, both families of Nitrososphaeraceae $(60 \%)$ and Nitrosopumilaceae $(28 \%)$ could be observed. The unclassified archaea at family level in DW WWTP, was belonged to the phylum of Woesearchaeota. Woesearchaeota attributed to about $60 \%$ of archaea, and other archaeal methanogenesis occupied about $30 \%$ of archaea in genus level in DW WWTP. Woesearchaeota were widespread archaea in aquatic ecosystem (Ortiz-Alvarez and Casamayor, 2016; Saghaï et al., 2017). However, our knowledge about the ecological role of Woesearchaeota was very limited, since there was no isolation or enrichment in phylum of Woesearchaeota so far. Recently, co-existence of Woesearchaeota and methanogenesis has been reported (Liu et al., 2018), which suggested host-dependent lifestyle of Woesearchaeota due to absence of genes for the complete TCA cycle. The high abundance of Woesearchaeota might relate to the injection of industrial wastewater in DW WWTP, there might be special organic compounds present in industrial wastewater which stimulated the growth of Woesearchaeota.

\subsection{Statistical Analyses}

To investigate correlations of bacterial and archaeal community composition with chemical factors in wastewater, CCA was performed as shown in Fig. 2. Nitrite, nitrate and TP concentration were strongly correlated with the diversity of bacterial and archaeal composition in WWTP samples, which suggested nitrite, nitrate and TP concentration were the most effective factors on bacterial and archaeal communities, than $\mathrm{pH}$ value, COD and sulfate concentration.

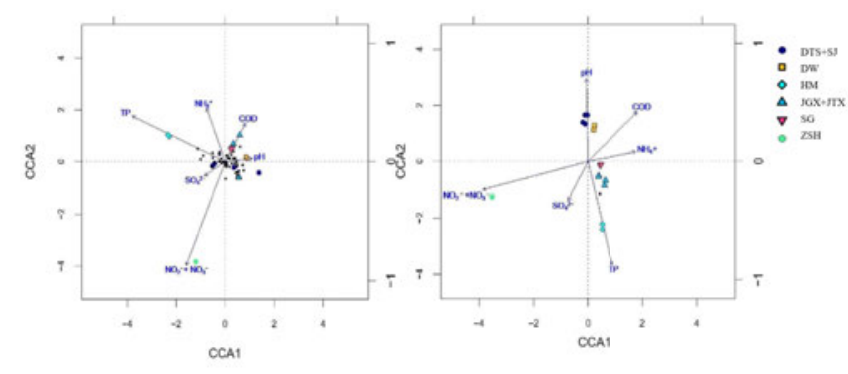

Figure 2. Ordination plots between environment variables and bacterial (A) and archaeal (B) lineages among WWTPs samples, based on 16s rRNA gene OTU results at family level using vegan package version 2.0-10. Sample plot was submerged according to city/district area.

\subsection{Abundance of Potential Nitrifiers, Denitri- fiers and Anammox Bacteria}

OTUs of known nitrifiers (Zhang et al., 2011; Wang et al., 2014; Fan et al., 2017), denitrifiers (Wang et al., 2014; Wang et al., 2015) and anammox bacteria (Wang et al., 2015; Meng et al., 2017; Hu et al., 2010) were selected at genus level, abundance of nitrifiers, denitrifiers and anammox OTU numbers in all WWTP sludge samples were shown in Fig. 3 and 4. It was not able to distinguish aerobic ammonia-oxidizing bacteria, nitrite oxidizing bacteria and comammox bacteria based on 16S rRNA genes at genus level. For instance, in 

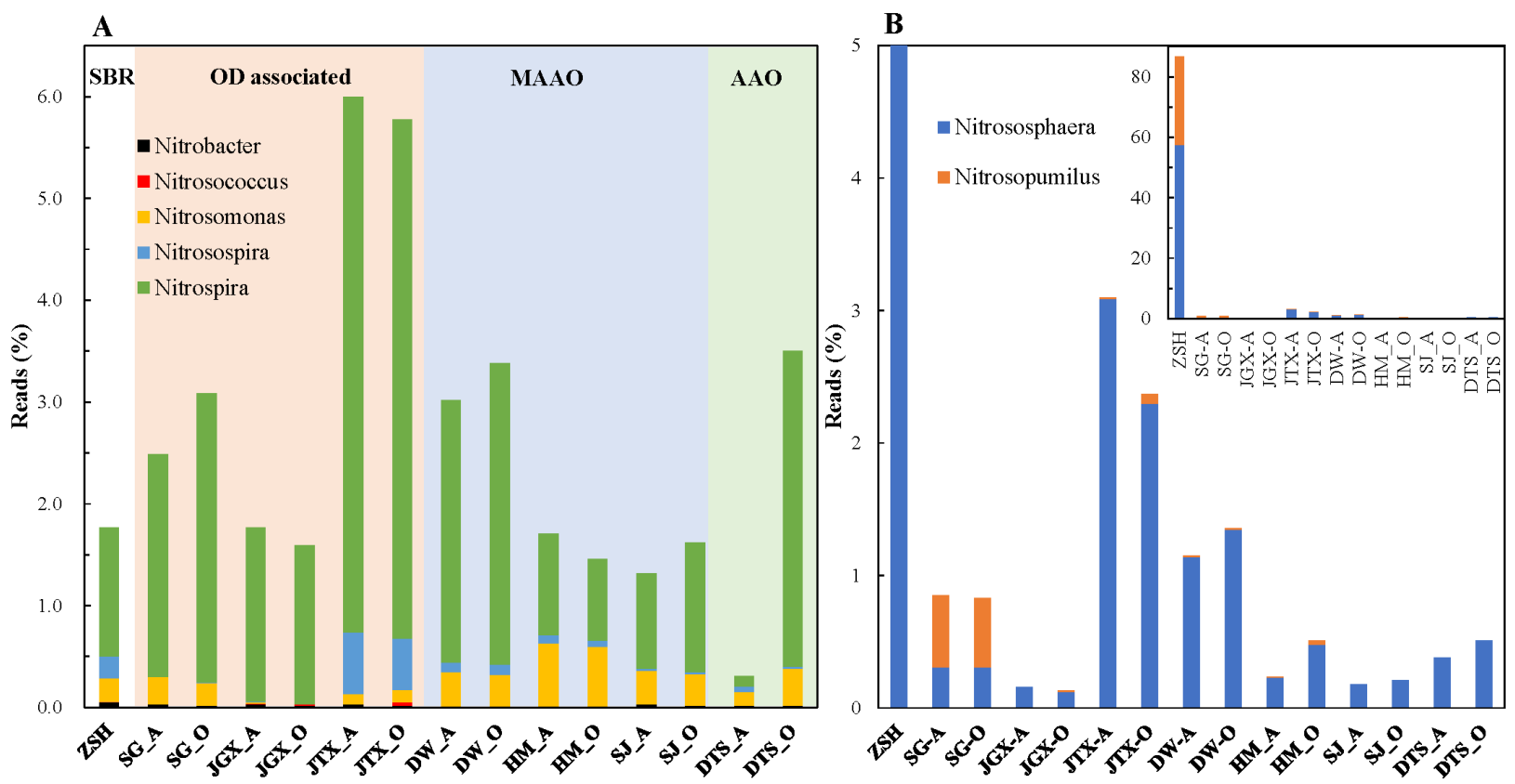

Figure 3. Diversity and relative abundance of potential aerobic ammonia-oxidizing bacteria (A), archaea (B) and nitrite oxidizing bacteria (A) of samples from WWTPS with different treatment processes, based on 16s rRNA gene reads.

the genus of Nitrospira, there were both aerobic nitrite oxidizers (Cébron and Garnier, 2005) and comammox (Van et al., 2015). Nitrosococcus mobilis was a nitrite oxidizer, but Nitrosococcus oceani was a widespread ammonia-oxidizing bacteria (Ward and O'Mullan, 2002). Therefore, all of Nitrobacter, Nitrosocuccus, Nitrosomonas, Nitrosospira and Nitrospira OTUs were merged as nitrifiers. The abundance of nitrifying bacteria in WWTP was very low, which only contributed to less than $3.5 \%$ of total bacterial communities, except sample from JTX WWTP (about 6\%). This was in consistence with previous studies (Zhang et al., 2011; Hai et al., 2014). Nitrospira sp. was dominate nitrifier in all samples, which might relate to both ammonium and nitrite oxidation. Abundance of AOA was very low in most of WWTP samples, which was less than $2.5 \%$ of total archaeal communities, except in ZSH WWTP (86.8\%). Nitrososphaera sp. was the majority AOA in all WWTP samples. A list of potential denitrifiers has been reported by Rosenberg (Rosenberg et al., 2013), 34 genera of denitrifiers could be detected among all WWTP samples in this study, as shown in Fig. 4A. Denitrifiers were sustainably more abundant in sludge samples from OD associated and SBR processes. Comamonas was dominate in WWTP with AAO process, Thermomonas and Dechloromonas were majority denitrifiers in OD associated WWTPs, Dechloromonas, Thiobacillus, Thauera, Azoarcus and Hyphomicrobium were relatively abundant denitrifers in WWTPs with MAAO process. Denitrifiers in SBR process were found to be evenly distributed by Comamonas, Thermomonas, Dechloromonas,
Thiobacillus, Azoarcus, Bdellovibrio, Hyphomicrobium and Defluviimonas. With exception of genus of Candidatus Jettenia, anammox bacteria belonged to all the rest 4 genera were detected in samples of WWTPs, including genera of $\mathrm{Ca}$. Kuenenia, Brocadia, Anammoxoglobus and Scalindua. However, the abundance of anammox bacteria were extremely low in sludge sample from WWTPs, which was more than 1000 times lower than denitrifiers, see Fig. 4. Anammox bacteria were hardly detected in SJ WWTP. The 4 genera of anammox bacteria were almost evenly distributed in sludge in SBR process, while the genera of Ca. Anammoxoglobus and Kuenenia were dominated in the rest seven WWTPs. Genera of Ca. Kuenenia and Brocadia were commonly dominated anammox bacteria in freshwater ecosystem, and (Wang et al., 2015; Meng et al., 2017; Langone et al., 2014; Hu et al., 2010). Ca. Anammoxoglobus were enriched from wastewater with addition of organic carbon, such as propionate (Kartal et al., 2007) and landfill leachate (Hsu et al., 2014), therefore, the observed abundance of Ca. Anammoxoglobus in WWTPs of PRD might related to organic compounds composition and concentration in this area. $\mathrm{Ca}$. Scalindua was widespread marine anammox bacteria, but there was also research indicated Ca. Scalindua anammox bacteria played important role in clean/ un-polluted paddy soil (Wang and Gu, 2013). Thus, the presence of Ca. Scalindua anammox bacteria might indicate relatively clean water the in ZSH WWTP, which was agreed with chemical data of wastewater. 


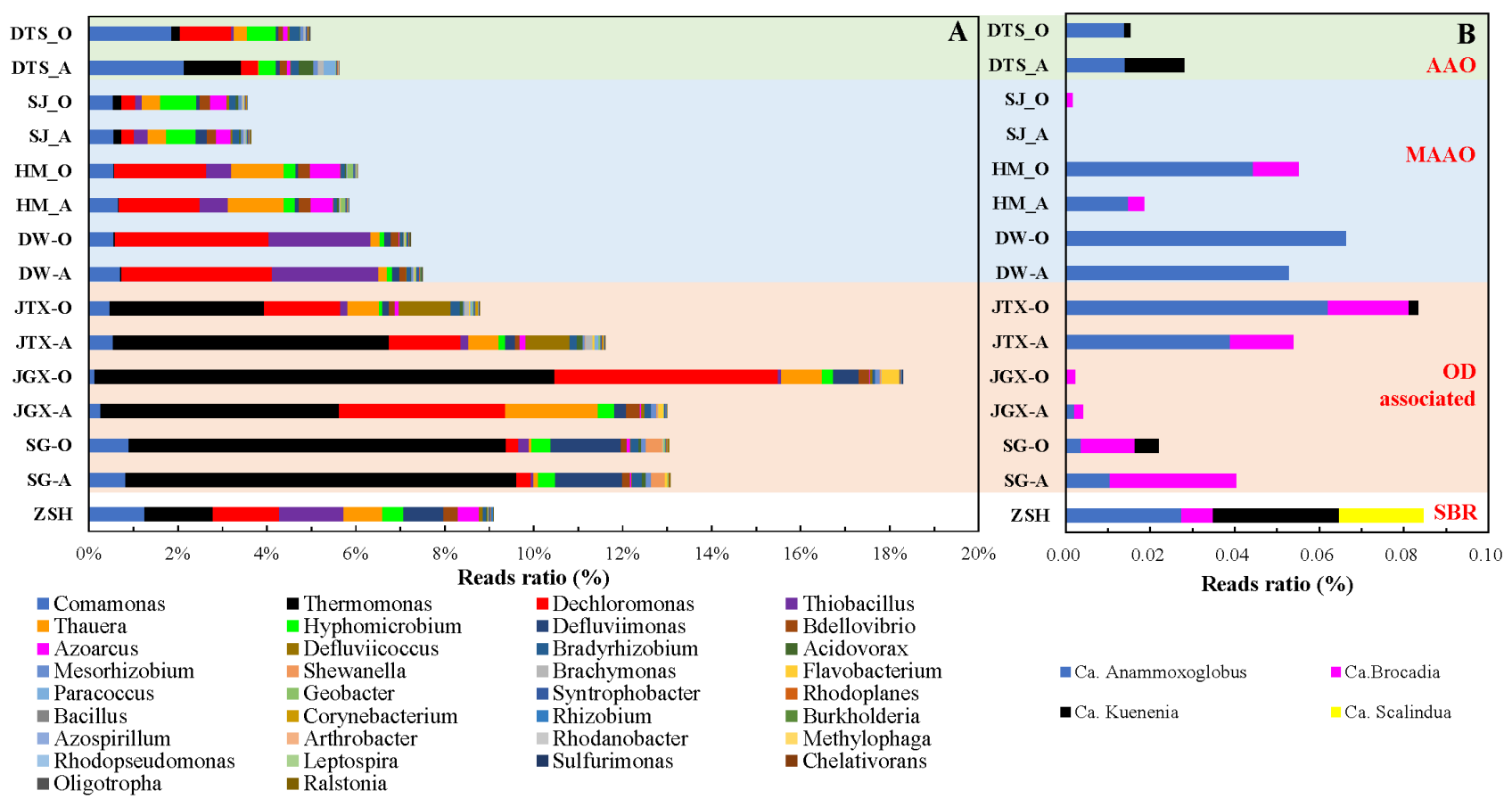

Figure 4. Diversity and relative abundance of potential denitrification (A) and anammox bacteria (B) of samples from WWTPS with different treatment processes, based on 16s rRNA gene reads.

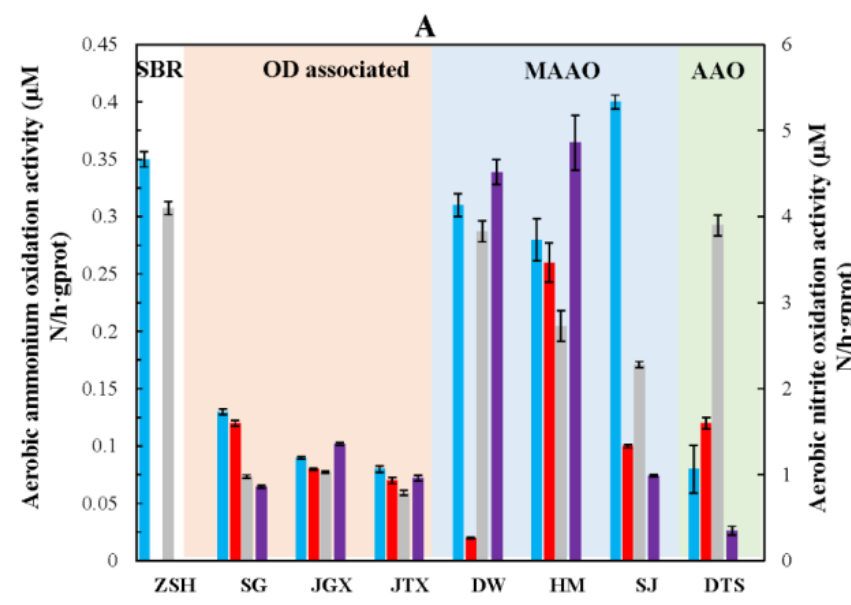

B

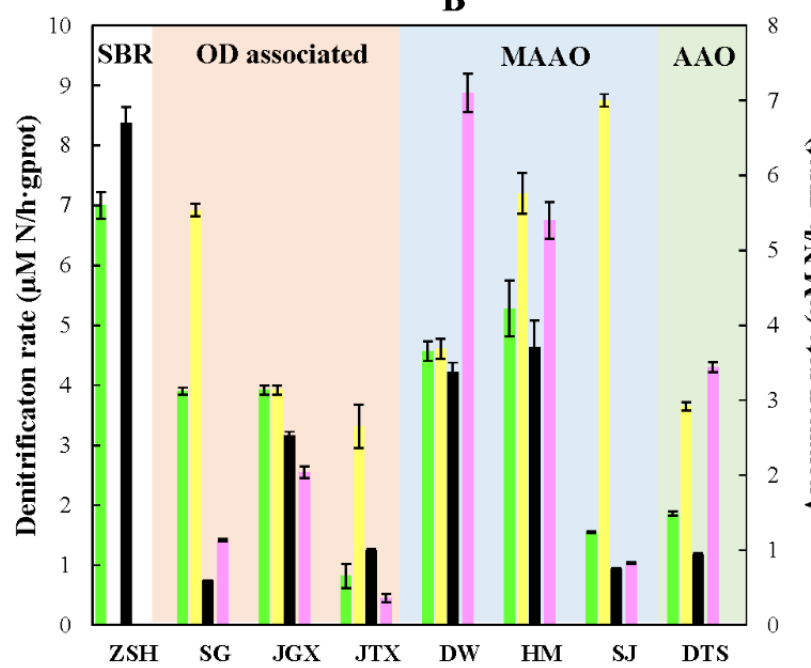

-Aerobic ammonia oxidation rate of aerobic biomass

-Aerobic ammonia oxidation rate of anaerobic biomass

$\square$ Aerobic nitrite oxidation rate of aerobic biomass

-Aerobic nitrite oxidation rate of anaerobic biomass

Denitrification rate of aerobic biomass

Denitrification rate of anaerobic biomass

-Anammox rate of aerobic biomass

Anammox rate of anaerobic biomass

Figure 5. Diversity and relative abundance of potential denitrification (A) and anammox bacteria (B) of samples from WWTPS with different treatment processes, based on $16 \mathrm{~s}$ rRNA gene reads. 
Table 2. Sequence summary and calculation of alpha diversity indices of the WWTPs samples

\begin{tabular}{|c|c|c|c|c|c|c|c|}
\hline \multicolumn{8}{|c|}{ Bacteria } \\
\hline \multirow[b]{2}{*}{ Sample ID } & \multirow{2}{*}{$\begin{array}{c}\text { Sequence } \\
\text { number }\end{array}$} & \multirow{2}{*}{$\begin{array}{c}\text { OTU } \\
\text { number }\end{array}$} & \multicolumn{2}{|c|}{ Richness } & \multicolumn{3}{|c|}{ Diversity } \\
\hline & & & $\begin{array}{l}\text { ACE } \\
\text { index }\end{array}$ & $\begin{array}{l}\text { Chao1 } \\
\text { index }\end{array}$ & $\begin{array}{c}\text { Shannon } \\
\text { index }\end{array}$ & Simpsons & Coverage \\
\hline ZSH & 40350 & 3113 & 3914.9 & 3873.17 & 6.57 & 0.005 & 0.98 \\
\hline SG_A & 57169 & 2996 & 4172.57 & 4047.69 & 6.15 & 0.0083 & 0.98 \\
\hline SG_O & 54908 & 2742 & 3809.02 & 3845.32 & 5.87 & 0.0113 & 0.98 \\
\hline JTX_A & 67093 & 3495 & 5018.02 & 4920.68 & 6.14 & 0.0068 & 0.98 \\
\hline JTX_O & 46937 & 3147 & 4472.03 & 4355.12 & 6.24 & 0.0067 & 0.98 \\
\hline JGX_A & 49708 & 2601 & 4673.81 & 3905.64 & 5.55 & 0.0248 & 0.98 \\
\hline JGX_O & 46222 & 2452 & 4259.84 & 3627.01 & 5.41 & 0.0259 & 0.98 \\
\hline DW_A & 87947 & 2731 & 4453.7 & 3735.08 & 5.51 & 0.0135 & 0.99 \\
\hline DW_O & 76678 & 2502 & 4210.06 & 3489.36 & 5.47 & 0.0137 & 0.99 \\
\hline HM_A & 43871 & 3310 & 4784.43 & 4651.38 & 6.14 & 0.0047 & 0.97 \\
\hline HM_O & 58825 & 3846 & 5228.14 & 5033.38 & 6.28 & 0.0042 & 0.98 \\
\hline SJ_A & 77737 & 3286 & 4694.73 & 4496.37 & 6.13 & 0.0064 & 0.99 \\
\hline SJ_O & 60085 & 3029 & 5167.7 & 4468.02 & 6.04 & 0.0075 & 0.98 \\
\hline DTS_A & 66728 & 2665 & 3518.82 & 3294.63 & 4.46 & 0.0771 & 0.99 \\
\hline DTS_O & 68414 & 2695 & 5148.33 & 4226.33 & 5.11 & 0.0437 & 0.98 \\
\hline \multicolumn{8}{|c|}{ Archaea } \\
\hline \multirow[b]{2}{*}{ Sample ID } & \multirow[b]{2}{*}{ Reads } & \multirow[b]{2}{*}{ OTUs } & \multicolumn{2}{|c|}{ Richness } & \multicolumn{3}{|c|}{ Diversity } \\
\hline & & & $\begin{array}{l}\mathrm{ACE} \\
\text { index }\end{array}$ & $\begin{array}{l}\text { Chaol } 1 \\
\text { index }\end{array}$ & $\begin{array}{c}\text { Shannon } \\
\text { index }\end{array}$ & Simpsons & Coverage \\
\hline ZSH & 43239 & 405 & 475.3 & 449.51 & 2.2 & 0.2807 & 1 \\
\hline SG_A & 57794 & 641 & 1333.17 & 1025.71 & 3.43 & 0.0722 & 1 \\
\hline SG_O & 57812 & 601 & 1143.19 & 847.64 & 3.49 & 0.0669 & 1 \\
\hline JTX_A & 58800 & 806 & 1553.26 & 1233.44 & 3.42 & 0.0834 & 0.99 \\
\hline JTX_O & 64418 & 785 & 1370.83 & 1135 & 3.46 & 0.08 & 1 \\
\hline JGX_A & 58830 & 843 & 1221.1 & 1156.07 & 3.01 & 0.1552 & 0.99 \\
\hline JGX_O & 63525 & 901 & 1298.7 & 1224.21 & 2.75 & 0.2307 & 0.99 \\
\hline DW_A & 69026 & 917 & 1223.9 & 1129.56 & 2.58 & 0.3266 & 1 \\
\hline DW_O & 70524 & 911 & 1222.9 & 1142.35 & 2.88 & 0.2413 & 1 \\
\hline HM_A & 77892 & 1279 & 1788.99 & 1662.93 & 3.86 & 0.0558 & 0.99 \\
\hline HM_O & 74735 & 1283 & 1746.85 & 1628.82 & 3.89 & 0.0555 & 0.99 \\
\hline SJ_A & 67644 & 989 & 1467.79 & 1354.46 & 3.5 & 0.0728 & 0.99 \\
\hline SJ_O & 75627 & 1053 & 1531.23 & 1444.05 & 3.52 & 0.0701 & 0.99 \\
\hline DTS_A & 72995 & 922 & 1268.95 & 1199.63 & 3.31 & 0.0845 & 1 \\
\hline DTS_O & 75663 & 1150 & 1645.72 & 1542.06 & 3.3 & 0.0988 & 0.99 \\
\hline
\end{tabular}

*A represented sludge taken from anoxic tank or area of WWTPs, O represented sludge taken from oxic/aerobic tank or area of WWTPs, there was only one sample be taken for SBR process.

\subsection{Effect of Wastewater Treatment Technol- ogy on Microbial Communities}

All sludge samples investigated in this study were collected in municipal WWTPs in PRD area, the presence of a shared OTUs might confirm similar function of all samples. However, community compositions were obviously different over samples using different biotechnology. AAO, OD, MAAO and SBR were widely used biotechnologies adapted from the traditional activated sludge process. The highest Shannon index was achieved in bacterial community from SBR process, followed by OD, MAAO and AAO process, which probably due to the powerful sludge retention in SBR and OD process, by wastewater treatment in a single tank (as shown in Fig. S1). This result was consisted with $\mathrm{Hu}$ (Hu, 2012), who reported higher bacterial Shannon index in OD process than $\mathrm{AAO}$ and $\mathrm{AO}$ processes. SBR process was widely used in enrichment of slowly growing microbes, such as anammox bacteria (Yan et al., 2010; Yan et al., 2012; Strous et al., 1999) and nitrite-dependent anaerobic methane oxidation (n-damo) bacteria (Ettwig et al., 2008; Hu et al., 2014).

The relative importance of AOB and AOA had been remained unclear since the discovery of AOA (Könneke et al., 2005), relative abundance and contribution of AOB and AOA were very different over studies, locations and ecosystems (Zhang et al., 2011; Park et al., 2006; Bai et al., 2012; Posmanik et al., 2014; Liu et al., 2016). In this study, it was demonstrated that abundance of AOA was dramatically higher in SBR process, which might due to the long sludge retention and low $\mathrm{F} / \mathrm{M}$ ratio in SBR process. The abundance of denitrifiers were sustainable higher in OD associated and SBR process, which were both one single tank wastewater treatment technology. Moreover, Nitrospira sp. was dominate nitrifiers in all samples, however, aerobic ammonium oxidation activity was very low in all samples, which might imply most of the Nitrospira sp. bacteria in WWTPs were noncomammox bacteria, but aerobic nitrite oxidizers (GonzalezMartinez et al., 2016).

\subsection{Inconsistency of Abundance and Activi- ties of Nitrogen Cycle Microbes}

Activities of aerobic ammonium oxidation, nitrite oxidation, denitrification and anammox were higher in WWTPs with SBR and MAAO processes, however, the abundance of AOA and denitrifiers were higher in SBR and OD associated processes. No remarkable difference could be obtained for the relative abundance of nitrifiers and anammox bacteria over samples from the different treatment process in this study. In fact, the abundance of microbes was not always accordance with contribution of microbes, which indicated the presence of microbes without activity. For instance, nitrification activity was decreasing while stable bacterial and archaeal amoA gene was detected in soil ecosystem (Fisk et al., 2015), AOA activity was not dependent on the abundance of AOA in fertilization soil (Guo et al., 2017). Anammox bacteria abundance was not correlated to anammox activity in municipal WWTPs (Wang et al., 2015), which was in good agreement with this study.

As shown in Fig. S1, AAO and MAAO was a wastewater treatment process with individual anaerobic, anoxic and aerobic tanks, which led to lower sludge retention ability than SBR and OD processes. Therefore, lower microbial diversity and abundance in AAO and MAAO was observed than SBR and OD processes in this study. However, operation of AAO process required a large flow for recycling $(\mathrm{R}>300 \%)$, from aerobic tank to anoxic tank which brought nitrite/nitrate for denitrification in anoxic tank, thus, the activity of denitrifiers were inhibited by oxygen stress introduced by recycling flow. To avoid this problem, MAAO process introduced an additional pre-anoxic tank before anaerobic tank, and 
an aerobic tank before anoxic tank instead of recycling flow, see Fig. S1. Both carbon and nitrogen removal was enhanced, since the activity of each corresponding microorganism was optimized in MAAO (Sun et al., 2010). The higher nitrogen removal activity in SBR might relate to both microbial abundance and optimized operating condition, it was very convenient to adjust the retention time in SBR process, anaerobic, anoxic and aerobic process could be achieved in a single tank by intermittent-aeration (Dosta et al., 2007). Higher activity for pharmaceuticals removal in WWTPs could be detected in SBR and MBR processes, than AAO and OD processes (Liu et al., 2017). Besides, the relatively lower ammonium concentration in the effluent of SBR process might relate to the abundance of AOA in SBR, since extremely high ammonium affinity was found for AOA (132 nM) (Martens-Habbena et al., $2009)$ in comparison to $\mathrm{AOB}(>20 \mu \mathrm{M})$, which enabled ammonium scavenging. Therefore, the relatively higher nitrogen removal activities in SBR and MAAO processes, were not only related to the microbial abundance but also related to process configuration, which led to inconsistence of abundance and activities of nitrogen cycle microbes in WWTPs.

In this study, potential anammox activity was of the same magnitude as denitrification activity in all samples $(<10$-fold difference), although the abundance of anammox bacteria was over 1000 times lower than denitrifers. Potential denitrifiers which selected based on 16S rRNA genes might be non-denitrifiers, which led to miscount in abundance of dentrifiers. Different results obtained from 16s rRNA gene and amoA gene quantification was reported with aerobic ammonium oxidizers in WWTPs (Zhang et al., 2011).

\subsection{Potential Solution to Enhance Nitrogen Removal in WWTPs}

As discussed above, activity of aerobic ammonium oxidation was much lower than the activities of nitrite oxidation, denitrification and anammox, which most likely suggested aerobic ammonium oxidation was the limiting step for entire nitrogen removal process in WWTPs. CCA results further confirmed this theory, since both bacterial and archaeal communities were most correlated to nitrite/nitrate concentration in the tank. Based on above discussion, activity of aerobic ammonium oxidation, was related to both AOB/AOA abundance and treatment process configuration. Therefore, a few potential solutions were suggested to enhance aerobic ammonium oxidation in WWTPs: 1) designing and operating WWTPs with technology which was able to optimize the activity of aerobic ammonium oxidation, such as SBR and MAAO, application of SBR process might promote ammonium scavenger in effluent because of the abundance of AOA; 2) bio-augmentation of AOB culture in WWTPs to enhance abundance and activity of nitrifiers (Nejidat et al., 2006; Tang and Chen, 2015; Li et al., 2018) introducing earthworms to enhance aerobic ammonium oxidation in constructed wetland for municipal wastewater treatment, which led to increase of AOB biomass and activity (Emamjomeh et al., 2017; Xu et al., 2016).

\section{Conclusions}

Microbial communities and nitrogen removal activities of 8 municipal WWTPs were shaped by treatment technologies. Higher microbial diversities and nitrogen removal activities were observed in SBR and MAAO processes, than OD and AAO processes. Lack of nitrite/nitrate was the limiting factor for the entire nitrogen removal in WWTPs, due to low aerobic ammonium oxidation activity. Therefore, enhancing activity of aerobic ammonium oxidation was of crucial importance for nitrogen removal in WWTPs. Technology preference, bioaugmentation of AOB culture and introduction of earthworms might be potential solutions to enhance ammonium oxidation activity in WWTPs. Supplementary information of this work can be found in online version.

\section{Acknowledgements}

This work was supported by National Natural Science Foundation of China [51708142, 41576123 and 51778156], Science and Technology Program of Guangzhou [201707010256], and Pearl River S\&T Nova Program of Guangzhou [201806010191].

\section{Conflict of Interest}

The authors declare no conflict of interest.

\section{References}

American Public Health Association (APHA), American Water Works Association (AWWA) and Water Environment Federation (WEF), 2005, Standard Methods for the Examination of Water and Wastewater. Washington, D.C.:USA http://www.doi.org/10.1007/BF02996984

Arrigo, K.R., 2005. Erratum: marine microorganisms and global nutrient cycles. Nature, 437, 349-355.

http://www.doi.org/10.1099/00207713-47-1-150

Bai, Y., Sun, Q., Wen, D. and Tang, X., 2012. Abundance of ammonia-oxidizing bacteria and archaea in industrial and domestic wastewater treatment systems. FEMS Microbiology Ecology, 80, 323-330. http://www.doi.org/10.1111/j.1574-6941.2012.01296.x

Brenner, A., 2010. Removal of nitrogen and phosphorus compounds in biological treatment of municipal wastewater in Israel. Israel Journal of Chemistry, 46, 45-51.

Castellano-Hinojosa, A., Correa-Galeote, D., Carrillo, P., Bedmar, E.J. and Medina-Sánchez, J.M., 2017. Denitrification and biodiversity of denitrifiers in a high-mountain mediterranean lake. Frontiers in Microbiology, 8, 1911.

http://www.doi.org/10.3389/fmicb.2017.01911 
Cébron, A. and Garnier, J., 2005. Nitrobacter, and Nitrospira, genera as representatives of nitrite-oxidizing bacteria: detection, quantification and growth along the lower seine river (France). Water Research, 39, 4979-4992. http://www.doi.org/10.1016/j.watres.2005.10.006

Cheema, S., Zeyer, J. and Henneberger, R., 2015. Methanotrophic and methanogenic communities in Swiss alpine fens dominated by Carex rostrata and Eriophorum angustifolium. Applied and Environmental Microbiology, 81, 5832. http://www.doi.org/10.1128/AEM.01519-15

Cloern, J.E., 2001. Our evolving conceptual model of the coastal eutrophication problem. Marine Ecology Progress Series, 210, 223-253. http://www.doi.org/10.3354/meps210223

Cortés-Lorenzo, C., Sipkema, D., Rodríguez-Díaz, M., Fuentes, S., Juárez-Jiménez, B., Rodelas, B., Smidt, H. and GonzálezLópez, J., 2014. Microbial community dynamics in a submerged fixed bed bioreactor during biological treatment of saline urban wastewater. Ecological Engineering, 71, 126132. http://www.doi.org/10.1016/j.ecoleng.2014.07.025

Dosta, J., Galí, A., Benabdallah, E.T., Macé, S. and Mata-Alvarez, J., 2007. Operation and model description of a sequencing batch reactor treating reject water for biological nitrogen removal via nitrite. Bioresource Technology, 98, 2065-2075. http://www.doi.org/10.1016/j.biortech.2006.04.033

Emamjomeh, M.M., Tahergorabi, M., Farzadkia, M. and Bazrafshan, E., 2017. A review of the use of earthworms and aquatic worms for reducing sludge produced: an innovative ecotechnology. Waste and Biomass Valorization, 10, 1-15. http://www.doi.org/10.1007/s12649-017-9907-z

Ettwig, K.F., Shima, S., van, de, Pas-Schoonen, K.T., Kahnt, J., Medema, M.H., Op, den, Camp, H.J.M., Jetten, M.S.M. and Strous, M., 2008. Denitrifying bacteria anaerobically oxidize methane in the absence of archaea. Environmental Microbiology, 10, 3164-3173. http://www.doi.org/10.1111/j.1462-2920.2008.01724.x

Fan, X.Y., Gao, J.F., Pan, K.L., Li, D.C. and Dai, H.H., 2017. Temporal dynamics of bacterial communities and predicted nitrogen metabolism genes in a full-scale wastewater treatment plant. RSC Advances, 7, 56317-56327.

Figuerola, E.L. and Erijman, L., 2010. Diversity of nitrifying bacteria in a full-scale petroleum refinery wastewater treatment plant experiencing unstable nitrification. Journal of Hazardous Material, 181, 281-288. http://www.doi.org/10.1016/j.jhazmat.2010.05.009

Fisher, T.R., 1985. Review: the marine nitrogen cycle. Ecology, 1, 315-316. http://www.doi.org/10.2307/1941340

Fisk, L.M., Maccarone, L.D., Barton, L. and Murphy, D.V., 2015. Nitrapyrin decreased nitrification of nitrogen released from soil organic matter but not amoA gene abundance at high soil temperature. Soil Biology and Biochemistry, 88, 214-223. https://www.doi.org/10.1016/j.soilbio.2015.05.029

Gantner, S., Andersson, A.F., Alonso-Sáez, L. and Bertilsson, S., 2011. Novel primers for 16s rRNA-based archaeal community analyses in environmental samples. Journal of Microbiological Methods , 84, 12-18. http://www.doi.org/10.1016/j.mimet.2010.10.001

Gonzalez-Martinez, A., Rodriguez-Sanchez, A., van, Loosdrecht, M.C.M., Gonzalez-Lopez, J. and Vahala, R., 2016. Detection of comammox bacteria in full-scale wastewater treatment bioreactors using tag -454-pyrosequencing. Environmental Science and Pollution Research, 23, 25501-25511. http://www.doi.org/10.1007/s11356-016-7914-4

Guo, J., Ling, N., Chen, H., Zhu, C., Kong, Y.L., Wang, M., Shen, Q.R. and Guo, S.W., 2017. Distinct drivers of activity, abundance, Diversity and composition of ammonia-oxidizers: evidence from a long-term field experiment. Soil Biology and Biochemistry, 115, 403-414. https://www.doi.org/10.1016/j.soilbio.2017.09.007

Hai, R., Wang, Y., Wang, X., Li, Y. and Du, Z.Z., 2014. Bacterial community dynamics and taxa-time relationships within two activated sludge bioreactors. PLoS One, 9, e90175. http://www.doi.org/10.1371/journal.pone.0090175

Harter, J., Weigold, P., El-Hadidi, M., Huson, D.H., Kappler, A. and Behrens, S., 2016. Soil biochar amendment shapes the composition of n 2 o-reducing microbial communities. Science of The Total Environment, 562, 379-390. http://www.doi.org/10.1016/j.scitotenv.2016.03.220

Herlemann, D.P., Labrenz, M., Jürgens, K., Bertilsson, S., Waniek, J.J. and Andersson, A.F., 2011. Transitions in bacterial communities along the $2000 \mathrm{~km}$ salinity gradient of the baltic sea. The ISME Journal, 5, 1571-1579. http://www.doi.org/10.1038/ismej.2011.41

Herrmann, M., Opitz, S., Harzer, R., Totsche, K.U. and Küsel, K., 2017. Attached and suspended denitrifier communities in pristine limestone aquifers harbor high fractions of potential autotrophs oxidizing reduced iron and sulfur compounds. Microbial Ecology, 74, 1-14. http://www.doi.org/10.1007/s00248-017-0950-x

Hsu, S.C., Lai, Y.C., Hsieh, P.H., Cheng, P.J., Wong, S.S. and Hung, C.H., 2014. Successful enrichment of rarely found Candidatus anammoxoglobus propionicus from leachate sludge. Journal of Microbiology and Biotechnology, 24(7), 879-887. http://www.doi.org/10.4014/jmb.1401.01016

Hu, B.L., Zheng, P., Tang, C.J., Chen, J.W., van, der, Biezen, E., Zhang, L., Ni, B.J., Jetten, M.S.M., Yan, J., Yu, H.Q. and Kartal, B., 2010. Identification and quantification of anammox bacteria in eight nitrogen removal reactors. Water Research, 44, 5014-5020. http://www.doi.org/10.1016/j.watres.2010.07.021.

Hu, B.L., He, Z.F., Sha, G., Cai, C., Lou, L.P., Zheng, P. and $\mathrm{Xu}$, X.H., 2014. Cultivation of nitrite-dependent anaerobic methane-oxidizing bacteria: impact of reactor configuration. Applied Microbiology and Biotechnology , 98, 7983-7991. http://www.doi.org/10.1007/s00253-014-5835-z

Hu, M., Wang, X., Wen, X. and Xia, Y., 2012. Microbial community structures in different wastewater treatment plants as revealed by 454 -pyrosequencing analysis. Bioresource Technology, 117, 72-79. http://www.doi.org/10.1016/j.biortech.2012.04.061

Huang, X.P., Huang, L.M. and Yue, W.Z., 2003. The characteristics of nutrients and eutrophication in the pearl river estuary, South China. Marine Pollution Bulletin, 47, 30-36. http://www.doi.org/10.1016/s0025-326x(02)00474-5

Jetten, M.S.M., Wagner, M., Fuerst, J., van, Loosdrecht, M., Kuenen, G. and Strous, M., 2001. Microbiology and application of the anaerobic ammonium oxidation ('anammox') process. Current Opinion in Biotechnology, 12, 283-288. http://www.doi.org/10.1016/S0958-1669(00)00211-1 
Kartal, B., Rattray, J., van, Niftrik, L.A., van, de, Vossenberg, J., Schmid, M.C., Webb, R.I., Schouten, S., Fuerst, J.A., Damste, J.S., Jetten, M.S. and Strous, M., 2007. Candidatus "anammoxoglobus propionicus" a new propionate oxidizing species of anaerobic ammonium oxidizing bacteria. Systematic and Applied Microbiology, 30(1), 39-49. http://www.doi.org/10.1016/j.syapm.2006.03.004

Könneke, M., Bernhard, A.E., de, la, Torre, J.R., Walker, C.B., Waterbury, J.B. and Stahl, D.A., 2005. Isolation of an autotrophic ammonia-oxidizing marine archaeon. Nature, 437, 543-546.

http://www.doi.org/10.1038/nature03911

Langone, M., Yan, J., Haaijer, S.C.M., Op, den, Camp, H.J., Jetten, M.S. and Andreottola, G., 2014. Coexistence of nitrifying, anammox and denitrifying bacteria in a sequencing batch reactor. Frontiers in Microbiology, 5, 28. http://www.doi.org/10.3389/fmicb.2014.00028

Le, C., Zha, Y., Li, Y., Sun, D., Lu, H. and Yin, B., 2010. Eutrophication of lake waters in china: cost, causes, and control. Environmental Management, 45, 662-668. http://www.doi.org/10.1007/s00267-010-9440-3

Li, L., Qian, G.S., Ye, L.L., Hu, X.M., Yu, X. and Lyu, W.J., 2018. Research on the enhancement of biological nitrogen removal at low temperatures from ammonium-rich wastewater by the bio-electrocoagulation technology in lab-scale systems, pilot-scale systems and a full-scale industrial wastewater treatment plant. Water Research, 140, 77. http://www.doi.org/10.1016/j.watres.2018.04.036

Liu, F., Zhang, S.N., Wang, Y., Li, Y., Xiao, R.L., Li, H.F., He, Y., Zhang, M.M., Wang, D., Li, X. and Wu, J.S., 2016. Nitrogen removal and mass balance in newly-formed myriophyllum aquaticum mesocosm during a single 28-day incubation with swine wastewater treatment. Journal of Environmental Management, 166, 596-604. http://www.doi.org/10.1016/j.jenvman.2015.11.020

Liu, H.Q., Lam, J.C., Li, W.W., Yu, H.Q. and Lam, P.K.S., 2017. Spatial distribution and removal performance of pharmaceuticals in municipal wastewater treatment plants in china. Science of The Total Environment, 586, 1162-1169. http://www.doi.org/10.1016/j.scitotenv.2017.02.107

Liu, X., Meng, L., Castelle, C.J., Probst, A.J., Zhou, Z.C., Pan, J., Liu, Y., Banfield, J.F. and Gu, J.D., 2018. Insights into the ecology, evolution, and metabolism of the widespread Woesearchaeotal lineages. Microbiome, 6, 102. http://www.doi.org/10.1186/s40168-018-0488-2

Ma, Q., Qu, Y,Y,, Zhang, X.W., Shen, W.L., Liu, Z.Y., Wang, J.W., Zhang, Z.J. and Zhou, J.T., 2015. Identification of the microbial community composition and structure of coalmine wastewater treatment plants. Microbiological Research, $175,1-5$. http://www.doi.org/10.1016/j.micres.2014.12.013

Martens-Habbena, W., Berube, P.M., Urakawa, H., de, la, Torre, J.R. and Stahl, D.A., 2009. Ammonia oxidation kinetics determine niche separation of nitrifying archaea and bacteria. Nature, 461, 976-979. http://www.doi.org/10.1038/nature08465.

Meng, H., Yang, Y.C., Lin, J.G., Denecke, M. and Gu, J.D., 2017. Occurrence of anammox bacteria in a traditional fullscale wastewater treatment plant and successful inoculation for new establishment. International Biodeterioration and Biodegradation, 120, 224-231.

http://www.doi.org/10.1016/j.ibiod.2017.01.022
Nejidat, A., Khaimov, A., Ronen, Z. and Brenner, A., 2006. Enhanced nitrification in industrial wastewater after augmentation by soil nitrifying enrichments. International Journal of Environmental Technology and Management, 6, 489-496. http://www.doi.org/10.1504/IJETM.2006.010480

Ortiz-Alvarez, R. and Casamayor, E.O., 2016. High occurrence of Pacearchaeota and Woesearchaeota (archaea superphylum DPANN) in the surface waters of oligotrophic high-altitude lakes. Environmental Microbiology Reports, 8(2), 210-217. http://www.doi.org/10.1111/1758-2229.12370

Pan, K.L., Gao, J.F., Li, H.Y., Fan X.Y., Li, D.C. and Jiang, H., 2018. Ammonia-oxidizing bacteria dominate ammonia oxidation in a full-scale wastewater treatment plant revealed by DNA-based stable isotope probing. Bioresource Technology, 256, 152-159. http://www.doi.org/10.1016/j.biortech.2018.02.012

Park, H.D., Wells, G.F., Bae, H. and Francis, C.A., 2006. Occurrence of ammonia-oxidizing archaea in wastewater treatment plant bioreactors. Applied and Environmental Microbiology, 72, 5643-5647. http://www.doi.org/10.1128/aem.00402-06

Posmanik, R., Gross, A. and Nejidat, A., 2014. Effect of high ammonia loads emitted from poultry-manure digestion on nitrification activity and nitrifier-community structure in a compost biofilter. Ecological Engineering, 140-147. http://www.doi.org/10.1016/j.ecoleng.2013.10.033

Qiu, Y., Shi, H. and He, M., 2010. Nitrogen and phosphorous removal in municipal wastewater treatment plants in china: a review. Int. J. Chem. Engineer, 2010, 10. http://www.doi.org/10.1155/2010/914159

Rosenberg, E., Delong, E.F., Thompson, F. and Lory, S., 2013. The prokaryotes: prokaryotic physiology and biochemistry. http://www.doi.org/10.1007/978-3-642-30141-4

Saghaï, A., Gutiérrezpreciado, A., Deschamps, P., Moreira, D., Bertolino, P., Ragon, M. and López-García P., 2017. Unveiling microbial interactions in stratified mat communities from a warm saline shallow pond. Environmental Microbiology, 19(6), 2405.

http://www.doi.org/10.1111/1462-2920.13754

Schloss, P.D., Westcott, S.L., Ryabin, T., Hall, J.R., Hartmann, M., Hollister, E.B., Lesniewski, R.A., Oakley, B.B., Parks, D.H., Robinson, C.J., Sahl, J.W., Stres, B., Thallinger, G.G., Van, Horn, D.J. and Weber, C.F., 2009. Introducing mothur: open-source, platform-independent, community-supported software for describing and comparing microbial communities. Applied and Environmental Microbiology, 75, 7537 7541.

http://www.doi.org/10.1128/AEM.01541-09

Strous, M., Fuerst, J.A., Kramer, E.H.M., Logemann, S., Muyzer, G., van, de, Pas-Schoonen, K.T., Webb, R., Kuenen, J.G. and Jetten, M.S., 1999. Missing lithotroph identified as Planctomycete. Nature, 400, 446-449.

http://www.doi.org/10.1038/22749

Sun, S.P., I, Nàcher, C.P., Merkey, B., Zhou, Q., Xia, S.Q., Yang, D.H., Sun, J.H. and Semts, B.F., 2010. Effective biological nitrogen removal treatment processes for domestic wastewaters with low $\mathrm{C} / \mathrm{N}$ ratios: a review. Environmental Engineering Science, 27, 111-126. http://www.doi.org/10.1089/ees.2009.0100

Sun, W., Xiao, E.Z., Pu, Z.L., Krumins, V., Dong, Y.R., Li, B.Q. and Hu, M., 2018. Paddy soil microbial communities driven 
by environment- and microbe-microbe interactions: a case study of elevation-resolved microbial communities in a rice terrace. Science of The Total Environment , 612, 884-893. http://www.doi.org/10.1016/j.scitotenv.2017.08.275

Takai, K. and Horikoshi, K., 2000. Rapid detection and quantification of members of the archaeal community by quantitative PCR using fluorogenic probes. Applied and Environmental Microbiology, 66, 5066-5072. http://www.doi.org/10.1128/AEM.66.11.5066-5072.2000

Tang, H.L. and Chen, H., 2015. Nitrification at full-scale municipal wastewater treatment plants: evaluation of inhibition and bioaugmentation of nitrifiers. Bioresource Technology, 190, 76-81.

http://www.doi.org/10.1016/j.biortech.2015.04.063

Thamdrup, B. and Dalsgaard, T., 2002. Production of N2 through anaerobic ammonium oxidation coupled to nitrate reduction in marine sediments. Applied and Environmental Microbiology, 68, 1312-1318. http://www.doi.org/10.1128/aem.68.3.1312-1318.2002

Tourna, M., Stieglmeier, M., Spang, A., Könneke, M., Schintlemeister, A., Urich, T., Engel, M., Schloter, M., Wagner, M., Richter, A. and Schleper, C., 2011. Nitrososphaera viennensis, an ammonia oxidizing archaeon from soil. Proceedings of the National Academy of Sciences of the United States of America, 108, 8420-8425. http://www.doi.org/10.1073/pnas.1013488108

Van, Kessel, M.A.H.J., Speth, D.R., Albertsen, M., Nielsen, P.H., Op, den, Campet, H.J.M., Kartal, B., Jetten, M.S.M. and Lücker, S., 2015. Complete nitrification by a single microorganism. Nature, 528, 555-559. http://www.doi.org/10.1038/nature16459

Wang, J. and Gu, J., 2013. Dominance of Candidatus Scalindua species in anammox community revealed in soils with different duration of rice paddy cultivation in northeast china. Applied Microbiology and Biotechnology, 97(4), 1785-1798. http://www.doi.org/10.1007/s00253-012-4036-x

Wang, Q., Garrity, G.M., Tiedje, J.M. and Cole, J.R., 2007. Naive bayesian classifier for rapid assignment of rRNA sequences into the new bacterial taxonomy. Applied and Environmental Microbiology, 73, 5261-5267. http://www.doi.org/10.1128/aem.00062-07

Wang, Z., Zhang, X.X., Lu, X., Liu, B., Li, Y., Long, C. and Li, A., 2014. Abundance and diversity of bacterial nitrifiers and denitrifiers and their functional genes in tannery wastewater treatment plants revealed by high-throughput sequencing. PLoS One, 9, e113603.

http://www.doi.org/10.1371/journal.pone.0113603

Wang, Z., Zhang, X.X., Lu, X., Liu, B., Li, Y., Long, C. and Li, A., 2014. Abundance and diversity of bacterial nitrifiers and denitrifiers and their functional genes in tannery wastewater treatment plants revealed by high-throughput sequencing. PLoS One, 9, e113603. http://www.doi.org/10.1371/journal.pone.0113603

Wang, S., Peng, Y., Ma, B., Wang, S.Y. and Zhu, G.B., 2015. Anaerobic ammonium oxidation in traditional municipal wastewater treatment plants with low-strength ammonium loading: widespread but overlooked. Water Research, 8, 6675 .

http://www.doi.org/10.1016/j.watres.2015.07.005

Ward, B.B. and O'Mullan, G.D., 2002. Worldwide distribution of nitrosococcus oceani, a marine ammonia-oxidizing $\gamma$ proteobacterium, detected by PCR and sequencing of $16 \mathrm{~s}$ rRNA and amoA genes. Applied and Environmental Microbiology, 68, 4153-7.

http://www.doi.org/10.1128/AEM.68.8.4153-4157.2002

Xu, D., Gu, J., Li, Y., Zhang, Y., Howard, A., Guan, Y.D., Li, J.H. and Xu, H., 2016. Purifying capability, enzyme activity, and nitrification potentials in December in integrated vertical flow constructed wetland with earthworms and different substrates. Environmental Science and Pollution Research, 23, 273-281.

http://www.doi.org/10.1007/s11356-015-5734-6

Yan, J., Op, den, Camp, H.J.M., Jetten, M.S.M., Hu, Y.Y. and Haaijer, S.C.M., 2010. Induced cooperation between marine nitrifiers and anaerobic ammonium-oxidizing bacteria by incremental exposure to oxygen. Systematic and Applied Microbiology, 33, 407-415. http://www.doi.org/10.1016/j.syapm.2010.08.003

Yan, J., Haaijer, S.C.M., Op, den, Camp, H.J.M., van, Niftrik, L., Stahl, D.A., Könneke, M., Rush, D., Sinninghe, Damsté, J.S., Hu, Y.Y. and Jetten, M.S.M., 2012. Mimicking the oxygen minimum zones: stimulating interaction of aerobic archaeal and anaerobic bacterial ammonia oxidizers in a laboratoryscale model system. Environmental Microbiology, 14, 31463158 .

http://www.doi.org/10.1111/j.1462-2920.2012.02894.x

Yan, J., Zhong, K.Q., Wang, S.J., Chen, Z.X., Hu, H.H., Jian, Z.Y., Wen, H.J. and Zhang, H.G., 2018. Carbon metabolism and sulfate respiration by a non-conventional Citrobacter freundii strain SR10 with potential application in removal of metals and metalloids. International Biodeterioration and Biodegradation. https://www.doi.org/10.1016/j.ibiod.2018.05.010

Zhang, T., Ye, L., Tong, A.H.Y., Shao, M.F. and Lok, S., 2011. Ammonia-oxidizing archaea and ammonia-oxidizing bacteria in six full-scale wastewater treatment bioreactors. Applied Microbiology and Biotechnology , 91, 1215-1225. http://www.doi.org/10.1007/s00253-011-3408-y

Zhu, G., Wang, S., Wang, W., Wnag Y., Zhou, L.L., Jiang, B., Op, den, Camp, H.J.M., Risgaard-Petersen, N., Schwark, L., Peng, Y.Z., Hefting, M.M., Jetten, M.S.M. and Yin, C.Q., 2013. Hotspots of anaerobic ammonium oxidation at landfreshwater interfaces. Nature Geoscience, 6, 103-107. http://www.doi.org/10.1038/NGEO1683 


\title{
Evaluation of nitrogen removal processes and microbial communities in eight full-scale municipal wastewater treatment plants
}

\author{
Jia Yan ${ }^{1,2,4}$, Jie-Hui Xie ${ }^{1}$, Si-Ji Wang ${ }^{1}$, Hong-Guo Zhang ${ }^{1,2,3,4}$, Jia-Peng Wu ${ }^{3}$, Yi-Guo Hong ${ }^{1,2,3,{ }^{*}}$ \\ ${ }^{1}$ School of Environmental Science and Engineering, Guangzhou University, Guangzhou 510006, P.R. China \\ ${ }^{2}$ Key Laboratory for Water Quality Security and Protection in Pearl River Delta, Ministry of Education, Guangzhou 510006, P.R. China \\ ${ }^{3}$ State Key Laboratory of Tropical Oceanography (LTO), South China Sea Institute of Oceanology, Chinese Academy of Sciences, \\ Guangzhou 510301, P.R. China \\ ${ }^{4}$ Guangzhou University-Linköping University Research Center on Urban Sustainable Development, Guangzhou University, Guangzhou \\ 510006, P.R. China
}

*Correspondence to: Yi-Guo Hong, School of Environmental Science and Engineering, Guangzhou University, Guangzhou 510006, P.R. China; Key Laboratory for Water Quality Security and Protection in Pearl River Delta, Ministry of Education, Guangzhou 510006, P.R. China; State Key Laboratory of Tropical Oceanography (LTO), South China Sea Institute of Oceanology, Chinese Academy of Sciences, Guangzhou 510301, P.R. China; E-mail: yiguohong@gzhu.edu.cn

\section{DNA Extraction, PCR Amplification and Raw Data Analysis for High-throughput Sequencing for Sampling}

Genomic DNA of sludge sample was extracted with E.Z.N.ATM Mag-Bind Soil DNA Kit (Omega, USA). Purity of the extracted genomic DNA was checked on agarose gel, and concentration of DNA was quantified by using Qubit 3.0 fluorometer and kit (Invitrogen, USA). PCR amplification was performed in triplicate using a Gene Amp PCR-System ${ }^{\circledR} 9700$ (Applied Biosystems, USA) with the amount of $10 \mathrm{ng}$ of genomic DNA. 50 $\mu$ L PCR amplification solutions were prepared for each sample, containing $5 \mu \mathrm{L}$ of $10 \times$ PCR buffer, $0.5 \mu \mathrm{L}$ of $10 \mathrm{mMdNTP}, 10 \mathrm{ng}$ of Genomic DNA, $0.5 \mu \mathrm{L}$ of $50 \mu \mathrm{M}$ Bar-PCR primer F, $0.5 \mu \mathrm{L}$ of $50 \mu \mathrm{M}$ Primer R, $0.5 \mu \mathrm{L}$ of $5 \mathrm{U} / \mu \mathrm{L}$ PlantiumTaq and water. Thermal cycle steps for PCR were an initial denaturation at $94^{\circ} \mathrm{C}$ for $3 \mathrm{~min}$, and 5 cycles at $94^{\circ} \mathrm{C}$ for $30 \mathrm{~s}, 45^{\circ} \mathrm{C}$ for $20 \mathrm{~s}, 65^{\circ} \mathrm{C}$ for $30 \mathrm{~s}$, and additional 20 cycles at $94^{\circ} \mathrm{C}$ for $20 \mathrm{~s}, 55^{\circ} \mathrm{C}$ for $20 \mathrm{~s}$, and $72^{\circ} \mathrm{C}$ for $30 \mathrm{~s}$, and ended with a final extension step at $72^{\circ} \mathrm{C}$ for $5 \mathrm{~min}$. The obtained PCR product was purified by using Agencourt AMPure XP kit (Beckman, USA), and the purified PCR product was quantified again with Qubit 3.0 fluorometer (Invitrogen, USA).

Paired-end sequencing on Illumina Miseq platform was performed by Sangon Biotech (Shanghai, China). Sequencing reads were assigned to each sample according to the unique barcode of each sample. Pairs of reads from the original DNA fragments were firstly merged using FLASH (1.2.3), and then PRINSEQ (0.20.4) was used for the quality control of these merged reads. The barcode and primers then were removed. PCR chimeras were filtered out using Uchime (4.2.40). After the above filtration, the average length of all of the clean reads was $350 \mathrm{bp}$ and $430 \mathrm{bp}$. The sequences obtained were allocated phylogenetically down to the phylum, class and genus levels at $97 \%$ similarity for community composition analysis. For taxonomic analysis, the representative sequences from each OTU were subjected to the RDP-II Classifier of the Ribosomal Database Project (RDP) and the National Center for Biotechnology Information (NCBI) BLAST.

\section{Analytical Method}

Ammonium concentrations were determined with the use of ortho-phtaldialdehyde (OPA) reagent. $100 \mathrm{~mL}$ of sample was mixed with $2 \mathrm{~mL}$ of diluted OPA reagent (10-fold dilution in sodium phosphate buffer, $0.3 \mathrm{M} \mathrm{pH}$ 7.3) incubated (20 min, room temperature, in the dark) and measured with a fluorescence spectrophotometer (excitation $411 \mathrm{~nm}$, emission $482 \mathrm{~nm}$, slit size $5 \mathrm{~nm}, 600 \mathrm{~V}$ ). Nitrite, nitrate and sulfate concentration in liquid samples were analyzed by ion chromatography (DIONEX ICS-1100, Thermo Fisher, USA), with retention time of 9,13 and 16 min, respectively. Sodium bicarbonate and carbonate was used as eluents. 

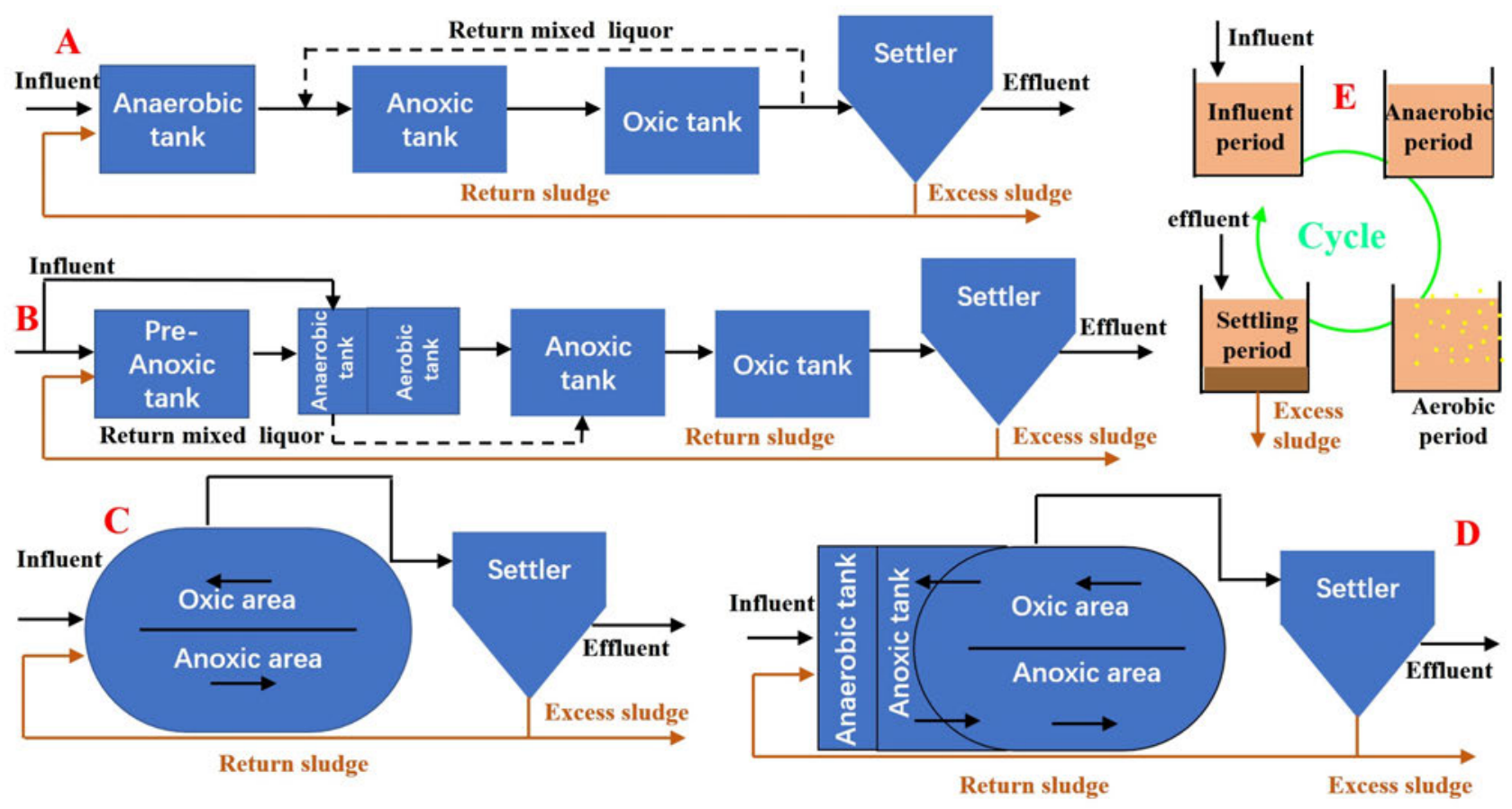

Figure S1. Diagrams for treatment biotechnologies of sampling WWTPs, A, AAO process, B, modified AAO process, C, OD process, D, AA-OD process, E, SBR process.
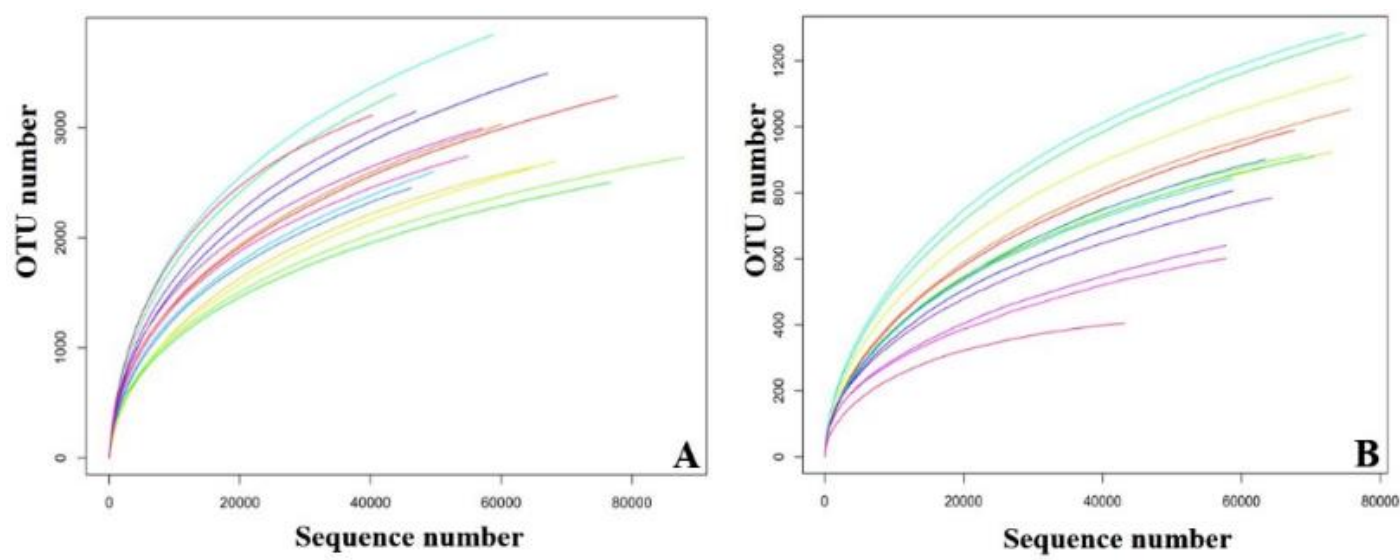

DTS_A

- SJ_A

- HM_A

- JGX_A

- JTX_A

- SG_A

- DW_A

Z ZSH
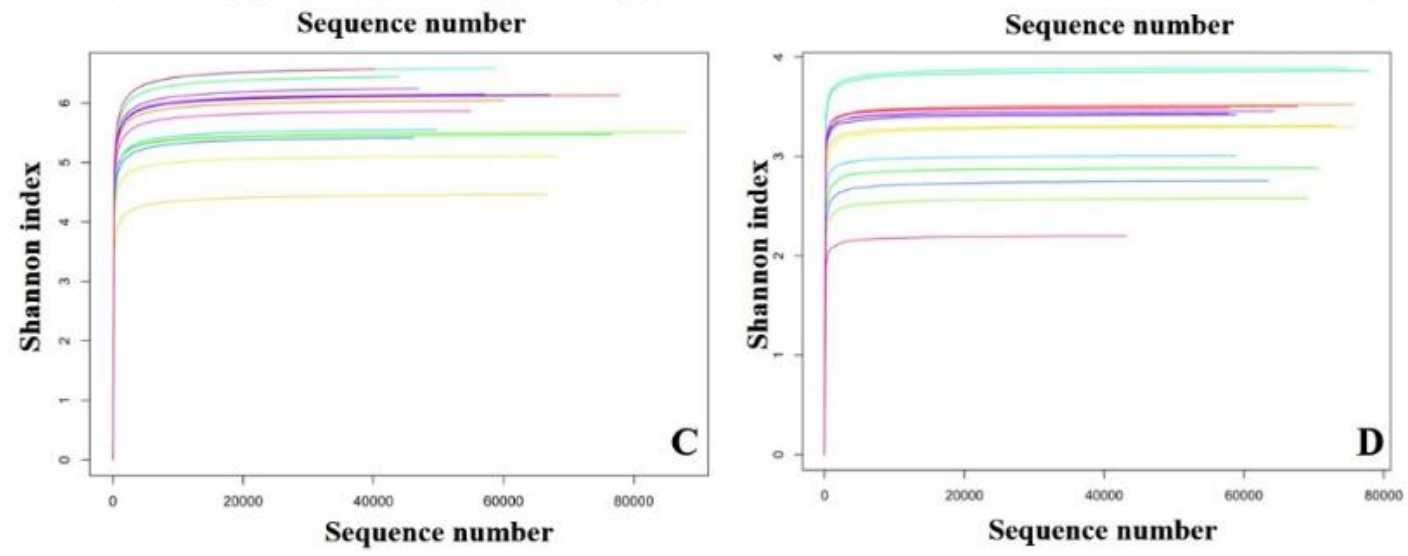

DTS_O

- SJ_O

HM_O

JGX O

- JTX_O

SG_O

DW_O

Figure S2. Rarefaction curves of OTUs and Shannon index curves created in mothur (97\% sequence similarity) for the bacterial (A,C) and archaeal (B,D) communities of each WWTP samples. 

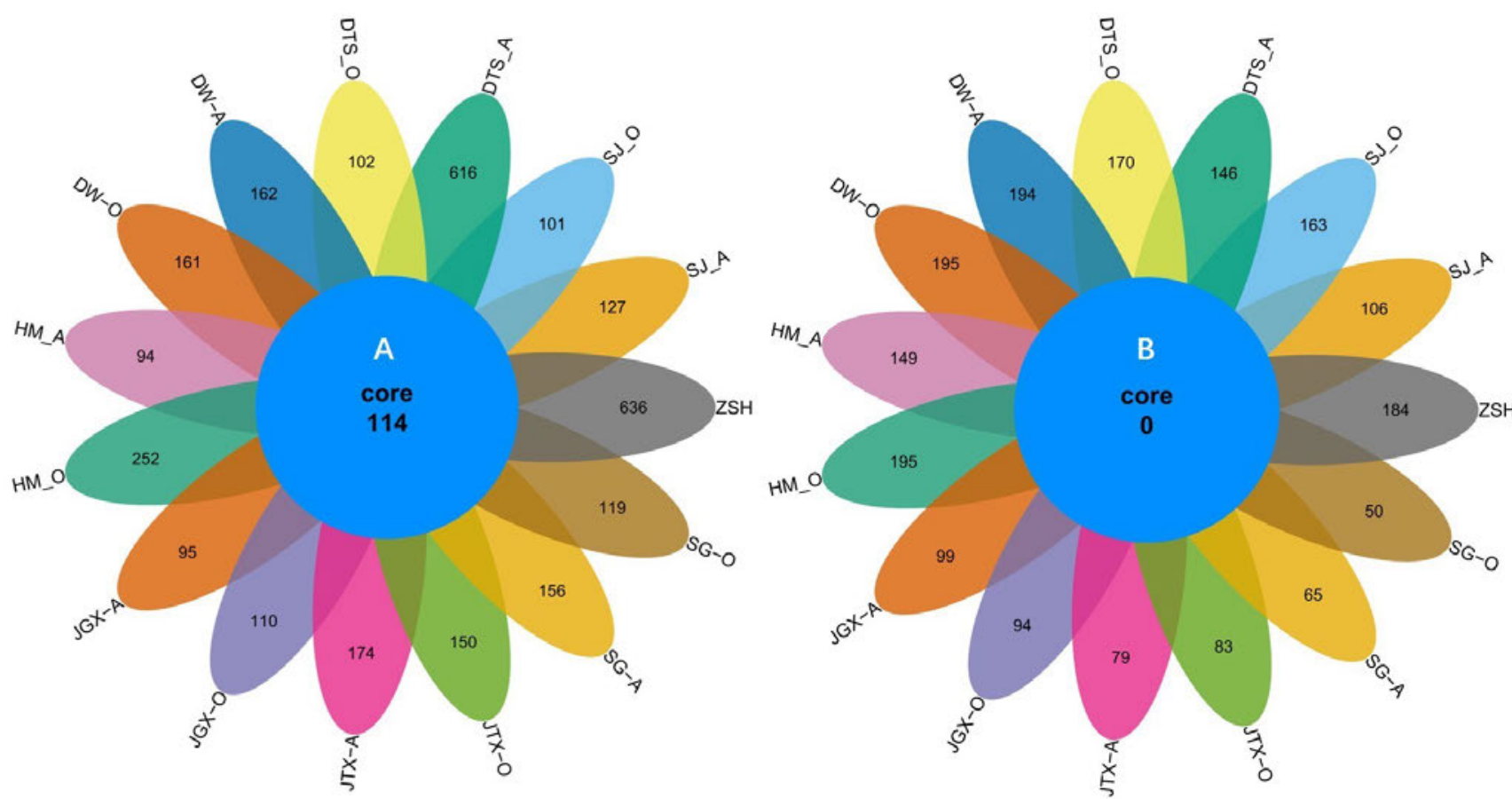

Figure S3. Venn diagram demonstrating bacterial (A) and archaeal (B) unique and shared core OTUs among WWTPs samples.

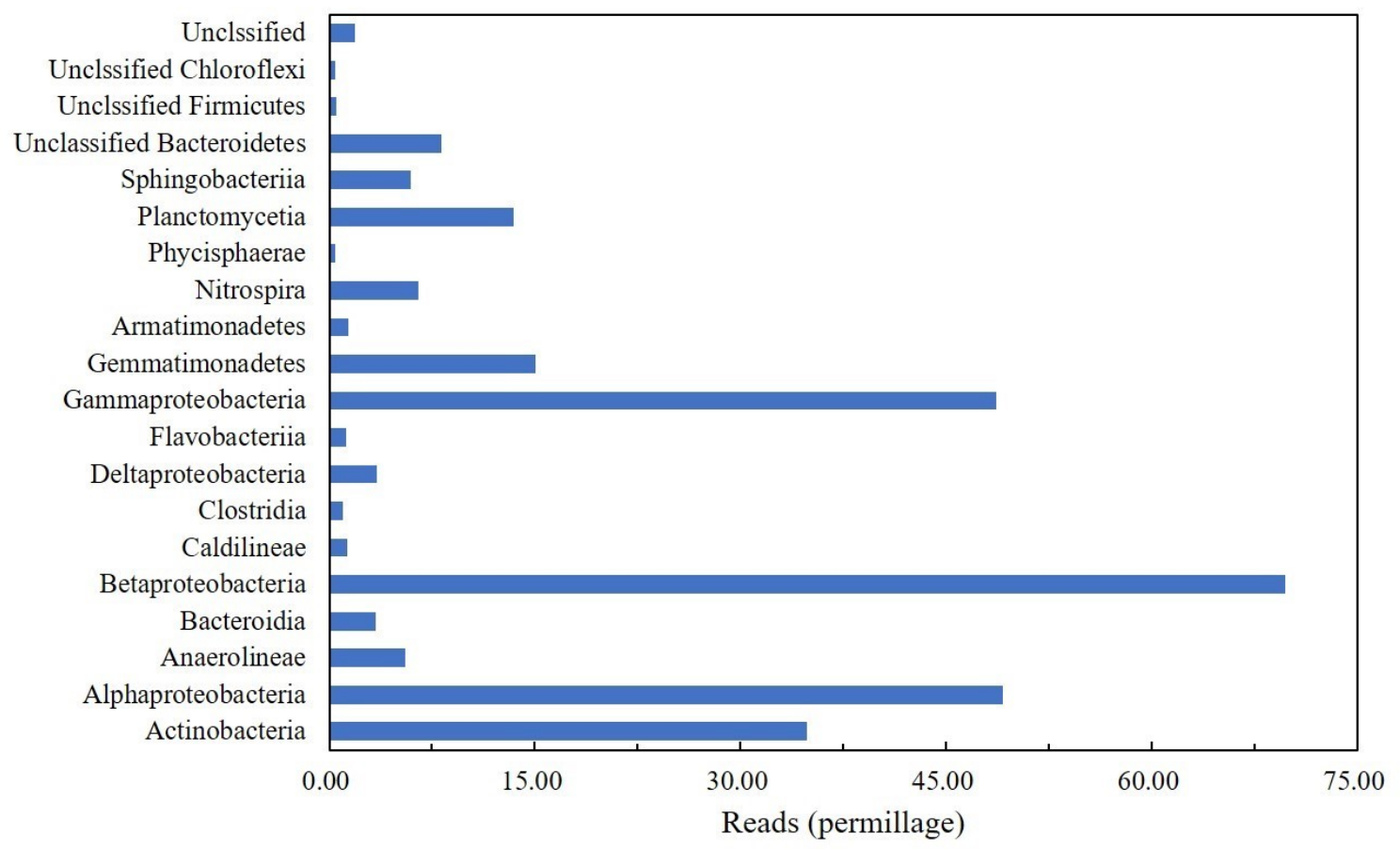

Figure S4. Shared bacterial OTUs among WWTP samples. 


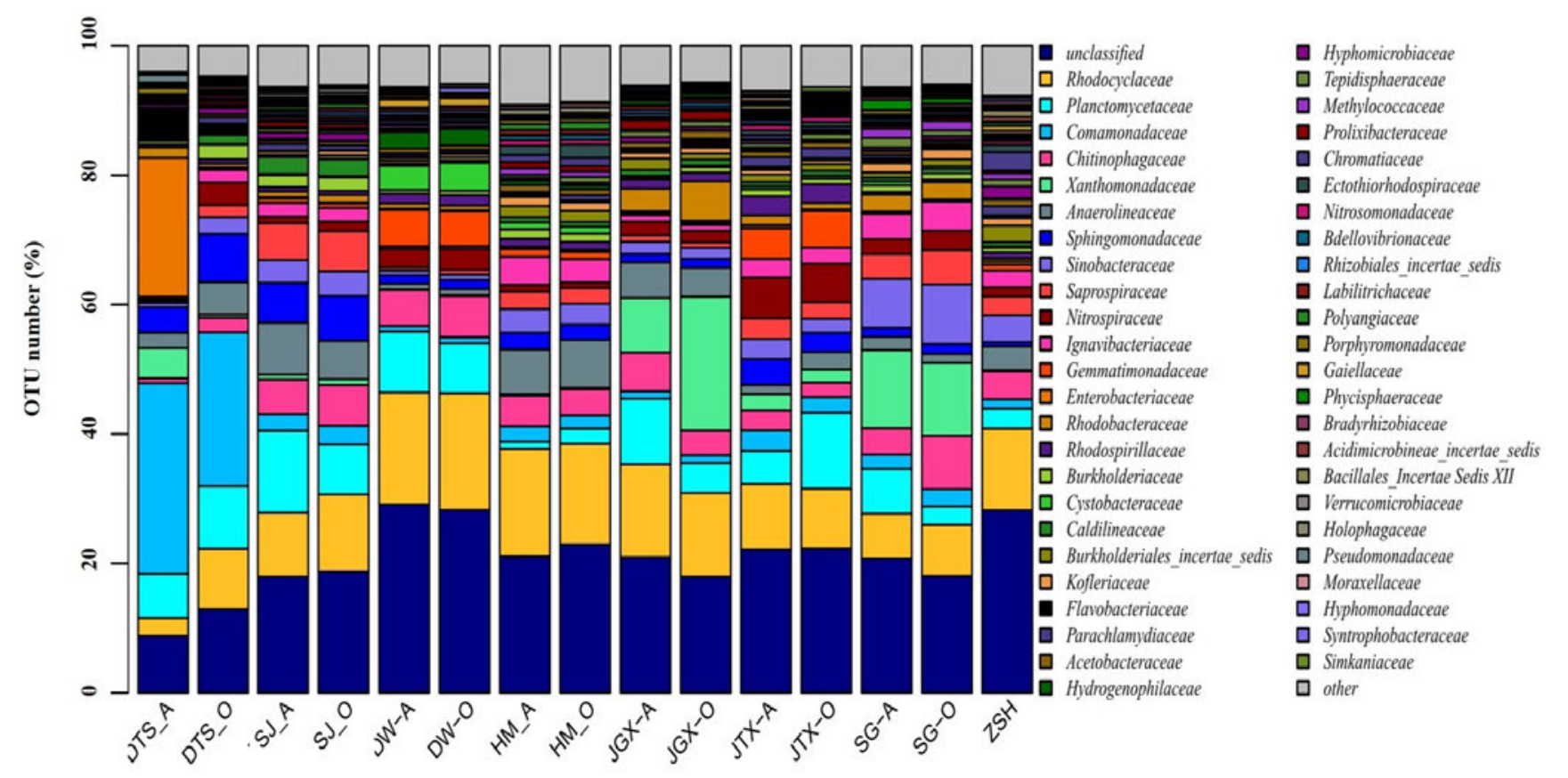

Figure S5. Relative abundance of bacteria at family level in each WWTPs samples.

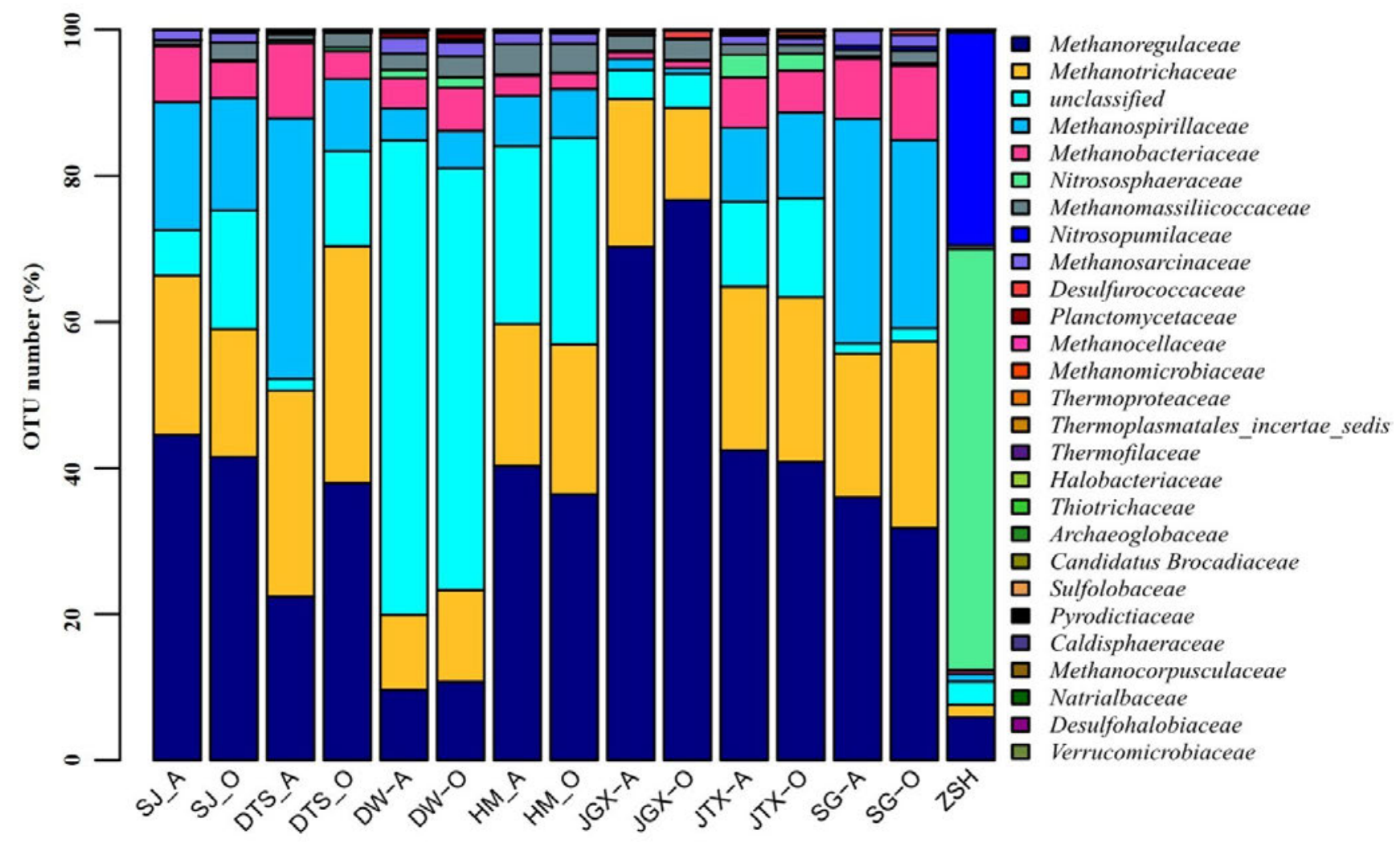

Figure S6. Relative abundance of archaea at family level in each WWTPs samples. 